\title{
Histochemical Assays of Secretory Trichomes and the Structure and Content of Selected Components in Rubus Idaeus L. Leaves
}

\author{
Mirosława Chwil*, Mikołaj Kostryco
}

\section{Mirosława Chwil*}

Department of Botany, University of Life Sciences in Lublin, Akademicka 15, 20-950 Lublin, Poland, e - mail: miroslawa.chwil@up.lublin.pl

*Mirosława Chwil - Corresponding author

\section{Mikołaj Kostryco}

Department of Botany, University of Life Sciences in Lublin, Akademicka 15, 20-950 Lublin, Poland, e - mail: kostryco@up.lublin.pl

\begin{abstract}
Leaves of Rubus idaeus are a raw material, ingredients of herbal blend and a source of antioxidants. There are no data concerning histochemistry of trichomes and little is known about the leaves structure of this species. The aim of this study was to determine the histochemistry of active compounds and the structure of glandular trichomes, micromorphology, anatomy and ultrastructure of leaves as well as content of elements. To determine the histochemistry of glandular trichomes different chemical compounds were used. The leaves structure was analysed using light, scanning, and transmission electron microscopes. The content of elements was determined with atomic absorption spectrometry and the microanalysis of the epidermis ultrastructure was carried out with transmission electron microscope equipped with a digital X-ray analyser. In glandular trichomes: polyphenols, terpenes, lipids, proteins, and carbohydrates were identified. The main elements in the ultrastructure of the epidermis were: $\mathrm{Na}, \mathrm{S}, \mathrm{Ca}, \mathrm{Mg}, \mathrm{B}, \mathrm{Mo}$, and $\mathrm{Se}$. In dry matter of leaves $\mathrm{K}, \mathrm{Mg}$, $\mathrm{Ca}, \mathrm{P}$, and Fe were dominant. Infusions from leaves are safe for health in terms of the $\mathrm{Cd}$ and $\mathrm{Pb}$ concentrations. Leaves can be a valuable raw material. Non-glandular trichomes prevent clumping of mixed raw materials in herbal mixtures.
\end{abstract}

Keywords: red raspberry; cuticle; stomata; micromorphology; anatomy; ultrastructure elements 


\section{Introduction}

The genus Rubus characterised by extensive morphological diversity comprises many species divided into 12 subgenera [1]. The complex taxonomy of this genus is based on various methods, e.g. assessment of genetic relationships between taxa with AFLP markers [2]. Currently, the cultivation of $R$. idaeus is increasing substantially due to the nutritional value of the fruit, consumer demand, use of the raw material in various branches of industry, and production of new economically profitable varieties recommended in commodity production $[3,4,5]$.

Plants from the genus Rubus, e.g. $R$. idaeus, $R$. licatus, $R$. saxatilis, and $R$. rosifolius, and their hybrids, provide various herbal raw materials $[6,7]$. Rubi folium is an important source of a variety of health-enhancing phytocompounds [8, 9, 10, 11]. Leaves of $R$. coreanus contain tannins (ellagic acid, sanguuin H-5), flawonoids (kempferol, quercetin) [12]. The beneficial effect of $R$. idaeus and Rubus plicatus leaf extracts on the human organism is mainly exploited in medicine and food industry. R. idaeus leaves exhibit high antioxidant activity $[11,13,14]$. One of the most important antioxidant enzymes contained in this raw material is catalase, which decomposes hydrogen peroxide particles, thus providing protection against negative effects of oxidative stress $[15,16]$. This indicates that $R$. idaeus leaves are a good source of exogenous antioxidants in the human diet and can be used as a main herbal raw material and a component of various herbal blends [9].

As reported by Tomaszewski et al. [17], trichomes in the leaf epidermis in plants from the genus Rubus are regarded as one of the most important traits for classification of the representatives of this genus and for determination of taxa at the level of series, sections, and even subgenera. The distribution, size, and shape of trichomes were found to vary between taxa [17, 18, 19]. Tomaszewski et al. [17] distinguished three types of trichomes in Rubus plants: simple eglandular (unbranched) trichomes, eglandular branched trichomes, and very short secretory uniseriate trichomes. Costea et al. [10] reported the presence of glandular trichomes on both surfaces of the $R$. idaeus epidermis. Despite the large variety of red raspberry cultivars and hybrids, there are insufficient literature data on the structure of the epidermis and leaf anatomy in this species. Therefore, an attempt to complete this knowledge has been undertaken. The present study is a continuation of previous investigations, in which bioactive compounds present in Rubi folium from several red raspberry cultivars were described [11]. 
The aim of this study was to determine and compare the histochemistry of active compounds and the structure of glandular trichomes, micromorphology, anatomy and ultrastructure of leaves as well as content of selected elements in the three R. ideaus varieties.

\section{Results}

\subsection{Morphology of the epidermis}

Non-glandular trichomes

There were sparse non-glandular trichomes in the adaxial epidermis of the leaves of the three analysed $R$. idaeus cultivars. The trichomes were unicellular, straight, bristly, and sharply pointed. In terms of the length, short, medium-length, and long trichomes were distinguished (Figures 1A, B; 3A, B; 5A - C).

The trichomes were also present on the surface of the midrib in the abaxial epidermis of the analysed cultivars. In other fragments of the abaxial epidermis, they were distributed less densely than the non-glandular trichomes. The surface of epidermis cells was visible between them (Figures 2B; 4B, C; 6C).

The non-glandular trichomes in the intercostal fields in the adaxial leaf epidermis were very long, twisted, and unicellular with a sharply pointed tip. They were distributed densely, masking the epidermis surface (Figures 2A, B; 4A, C; 6A, B).

\section{Glandular trichomes}

Secretory glandular trichomes were observed in the adaxial epidermis of the 'Laszka' and 'Radziejowa' leaves. No such structures were found in 'Glen Ample'. The glandular trichomes were located on the surface of the midrib epidermis. They were especially abundant on the midrib in the 'Laszka' cultivar (Figures 3A; 7A) and less dense in 'Radziejowa (Figure 5A). Glandular trichomes were also observed on successive branches of vascular bundles (Figures 3B, C, 5A, B).

The glandular trichomes had a multicellular elliptical or spherical head (20 - 26 cells in the outline) (Figure 7B - F). Due to exosecretion, the secretion accumulated in the subcuticular space formed a conical protuberance of the cuticle rupturing at the apex (Figure. $7 \mathrm{G}, \mathrm{H}$ ) or a typical spherical bulge (Figure 7I) at the apex of the trichome head. The height of 
the secretory head was $42 \mu \mathrm{m}$ and $53 \mu \mathrm{m}$ in 'Radziejowa' and 'Laszka', respectively. Its width was similar, i.e. in the range of $43-45 \mu \mathrm{m}$, in both cultivars. The head was located on a multi-celled, multiple-layered (2 layers in the outline) stalk. There were 3-7 stalk cells in one layer. The stalk in 'Radziejowa' was by $30 \%$ longer than the stalk in the 'Laszka' epidermis $(19 \mu \mathrm{m})$. The height of the glandular trichomes in both cultivars was similar $(69-71 \mu \mathrm{m})$. Their surface in the outline was in the range of 1419- $867 \mu \mathrm{m}^{2}$ (Table 1).

Histochemistry of glandular trichomes

For the first time, histochemical assays were employed to stain the selected groups of bioactive compounds in the glandular trichomes of $R$. ideaus 'Laszka' and 'Radziejowa'. Various groups of active compounds were detected. In the reaction with the Nadi reagent, terpene compounds present in the glandular trichomes were stained purple (Figure 8A). The reaction with Sudan Red 7B and Sudan Black B resulted in red (Figure 8B) and dark blue (Figure 8C, D) staining of lipid compounds, respectively. The Nile Blue stained acid lipids blue (Figure 8E, F). After application of Lugol's solution, pectin compounds exhibited a positive (yellow) staining reaction (Figure 8G, H). Fehling's reagent stained carbohydrates brown-red, whereas PAS reaction stained polysaccharides pink (Figure 8J). Addition of potassium dichromate or iron chloride yielded brown (Figure 8K) or black (Figure 8L) staining of polyphenolic compounds, respectively.

Cuticle

The outer wall of the adaxial epidermis cells in the analysed $R$. idaeus cultivars was tetra-, penta-, or hexagonal in the outline. The cuticle on its surface was smooth and had a fine wax coating (Figures 1A, C, D; 3A - D, 4A - D). In turn, the cuticle was striated on the stomata and on the midrib in the abaxial epidermis and smooth or delicately striated on the other epidermis cells (Figures 2A, D; 4C, D; 6C, D).

\section{Stomata}

The $R$. idaeus leaves are classified as the hypostomatic type. The stomata were located at the level or above the level of the other epidermis cells (Figures 2D; 4D;6D). The length and width of the stomata in the examined cultivars were in the range of $10-22 \mu \mathrm{m}$ and $8-19 \mu \mathrm{m}$, 
respectively. The largest and the smallest stomata were found in the epidermis of 'Radziejowa' and 'Laszka', respectively. The stomata were characterised by thick cuticular ledges $(1.9-3 \mu \mathrm{m})$. The length of the groove between the ledges ranged from 5 ('Laszka') to 12 ('Radziejowa') $\mu \mathrm{m}$ (Table 2).

\subsection{Anatomy}

The largest and the smallest cells of the adaxial leaf epidermis were observed in 'Glen Ample' (19 $\mu \mathrm{m}$ height/24 $\mu \mathrm{m}$ length) and 'Radziejowa' $(17 / 17 \mu \mathrm{m})$, respectively. An inverse relationship in terms of this trait was found between these cultivars in the abaxial epidermis. The analysed leaves represent the bifacial type (Figure 9A, B, D-F). The palisade parenchyma cells formed two layers. The largest palisade cells in the subepidermal layer were noted in 'Glen Ample' (35 $\mu \mathrm{m}$ height/7 $\mu \mathrm{m}$ width). The values of these parameters in the other two cultivars, i.e. 'Laszka' and 'Radziejowa', were in the range of 25-29 $\mu \mathrm{m}$ and 8-9 $\mu \mathrm{m}$, respectively. The thickness of the palisade parenchyma and the lamina in 'Glen Ample' and 'Radziejowa' was similar, i.e. in the range of 51-52 $\mu \mathrm{m}$ and 121-125 $\mu \mathrm{m}$, respectively. The thinnest lamina and palisade parenchyma layer were observed in 'Laszka'. The palisade parenchyma layer in the examined cultivars accounted for approximately $41 \%$ of the lamina thickness. The ratio of the palisade to sponge parenchyma in the studied cultivars ranged from 1.1 ('Laszka') to 1.3 ('Glen Ample') (Table 3). W pobliżu wiązek przewodzących szczególnie w nerwie głównym widoczne były kryształy szczawianu wapnia w formie druz (Figure 9C). Near the large vascular bands, especially in the main vein, calcium oxalate crystals were visible (Figure 9C).

\subsection{Ultrastructure of epidermal and assimilation cells}

The epidermis cells in $R$. idaeus leaves produced a thick periclinal outer cell wall (fig. 10A). On the surface of the epidermis, there was a cuticle strand (Figure 10B-D). The protoplast of these cells contained a parietal cytoplasm and single mitochondria with a well-developed membrane system (Figure 10E). The palisade mesophyll cells had a large nucleus with thick nucleoplasm and a dark nucleolus (fig. 10A), varied degrees of vacuolization (Figures 10A, 2A, B), numerous plastids with a distinct thylakoid system (Figures 11A, 2B), mitochondria (Figure 11A, C), and Golgi apparatus composed of 4-6 cisternae and a number of dictiosomal vesicles (Figure 11D, E). 


\subsection{Microanalysis of elements in selected parts of epidermis cells}

The microanalysis of selected elements in the cuticle and the other constituents of the epidermis cell wall in the leaves of Rubus idaeus 'Glen Ample', 'Laszka', and 'Radziejowa' revealed a dominant concentration of nitrogen, sodium, sulphur, and calcium. In turn, N, Ca, $\mathrm{Mg}$, and $\mathrm{Na}$ were most abundant in the cytoplasm of the epidermis of these organs in the analysed cultivars, whereas $\mathrm{N}, \mathrm{Ca}, \mathrm{S}$, and $\mathrm{Na}$ were dominant in the vacuoles. Moreover, among the analysed components of the raspberry leaf epidermis B, Mo, and Se were present at the highest concentrations (Figure 12, 13).

\subsection{Content of elements in leaf dry mass}

The concentration of the $\mathrm{K}, \mathrm{Ca}, \mathrm{Mg}, \mathrm{P}, \mathrm{Fe}$, and $\mathrm{Na}$ macroelements in the analysed $R$. idaeus leaves differed between the cultivars. The elements were aligned according to the growing content as follows: $\mathrm{K}>\mathrm{Ca}>\mathrm{Mg}>\mathrm{P}>\mathrm{Fe}$ in 'Glen Ample', $\mathrm{K}>\mathrm{Ca}>\mathrm{P}>\mathrm{Mg}>\mathrm{Fe}$ ('Laszka'), and $\mathrm{K}>\mathrm{Mg}>\mathrm{Ca}>\mathrm{P}>\mathrm{Fe}$ ('Radziejowa'). The highest iron concentration was determined in the leaves of 'Laszka' ( $833 \mathrm{mg} / \mathrm{kg} \mathrm{d.w.);} \mathrm{it} \mathrm{was} \mathrm{three-fold} \mathrm{lower} \mathrm{in} \mathrm{'Radziejowa'} \mathrm{and} \mathrm{five-fold}$ lower in 'Glen Ample'. The amount of sodium in the three examined cultivars was below the limit of determination. In turn, the content of zinc was similar in the leaves of 'Laszka and 'Radziejowa' (40 mg/kg d.w.), and by ca. 14 \% lower in 'Glen Ample' than that in the other two cultivars. The highest concentration of copper was found in 'Laszka' (34,1 mg/kg d.w.), while the other two cultivars were characterised by a ca. $68 \%$ lower concentration of this microelement. The zinc content in the leaves of the three cultivars was similar and ranged from 34 to $40 \mathrm{mg} / \mathrm{kg}$ d.w. Trace elements, i.e. cadmium and lead, were present at very low concentrations (well below the permissible levels) in the leaves of the analysed cultivars (Table 4).

\section{Discussion}

\subsection{Micromorphology}

The leaves of the analysed $R$. idaeus cultivars represent the hypostomatic type. This type of lamina is present in Prunus laurocerasus [20] and plants from the genus Sorbus [21] 
and in Sorbaria [22]. The abaxial epidermis of the analysed $R$. idaeus leaves and those described in the literature had unicellular, twisted, non-glandular trichomes $[17,19]$. Their length in $R$. hirtus epidermis was $16 \mathrm{~mm}$ [23]. These trichomes, present in several tens of species from the genus Rubus, have been divided into three types (simple unbranched, branched, and very short) and three subtypes (short, medium-length, and long) [17]. The nonglandular trichomes in the three cultivars analysed in the present study can be classified as the first type and different subtypes.

The non-glandular trichomes in the intercostal fields in the abaxial epidermis were densely distributed, masking the epidermis surface in the three $R$. idaeus cultivars. As reported by Upadhyaya and Furness [18], there were 7-82 trichomes per $1 \mathrm{~mm}^{2}$ of the epidermis in several R. idaeus cultivars. Four groups have been distinguished according to the density of non-glandular trichomes: I <10\%, II 10 - 49\%, III 50 - $90 \%$, and IV >90\% [17]. In this division, the non-glandular trichomes in the adaxial epidermis described in the present study can be classified into the first group, while those present in the abaxial epidermis represent the third or fourth group.

Non-glandular trichomes in the epidermis serve various functions. They constitute a protective barrier against pests, e.g. from the genera Amphorophora and Tetranychus [24]. The presence of trichomes on the epidermis surface was found to reduce the number of pests feeding on $R$. idaeus leaves [19]. The size and topography of trichomes are modified by environmental conditions $[18,25]$. Their stable trait in some $R$. ideaus cultivars was used in genetic engineering to develop new varieties [18]. The cultivation work resulted in identification of chromosomal regions of genes encoding and regulating micromorphological traits that can be genetically controlled [26]. Therefore, some species with favourable traits, e.g. $R$. canescens, are often used in development of new taxa [17].

\subsection{Histochemistry}

Various groups of biologically active compounds were stained with the histochemical assays. The Nadi reagent stained terpene compounds purple. This group of compounds in Rubus suavissimus was represented by the dominant rubusoside and steviol monoside. These compounds are involved in biological activity [27]. Another chemotaxonomic function is served by diterpene glycosides identified in $R$. chingii leaves [28].

Lipid compounds in the trichomes were stained red, dark blue, or light blue using Sudan Red 7B, Sudan black B, or Nil blue, respectively. The compounds were 
characteristically stained in the trichome secretory head and stalk. Saturated as well as polyand monounsaturated fatty acids in the fat extracted from the $R$. idaeus leaves accounted for $54.9 \%, 39.4 \%$, and 5.6\%, respectively. $\alpha$-Linolenic acid (25.3\%) and oleic acid (3.6\%) were found to dominate in the omega 3 and omega 9 groups, respectively [11]. A substantial proportion of fat is contained in epicuticular wax. These are mainly long-chain aliphatic compounds and terpenyl esters ( $\alpha$ - and $\beta$ - amyrin and cycloartenol). By forming the structure of wax, these compounds provide protection against some organisms [29]. A similar role of metabolic resistance to pathogens is played by the proteins identified in $R$. idaeus leaves [30, $31]$.

After application of Lugol's solution, protein compounds exhibited a positive (yellow) staining reaction in the stalk and the secretory head. On average, this group of compounds accounted for $20 \%$ of air-dry matter of $R$. idaeus leaves [11]. Proteins exhibit developmental dependence [32]. They can bind hydrophobic ligands (flavonoids and plant hormones) [33, 34] and serve as flavonoid-type transporters [35].

Fehling's reagent stained carbohydrates brown-red, whereas the PAS reaction stained polysaccharides pink. The average content of absorbable carbohydrates and sugars in the leaves of the analysed species was $6 \%$ and $5 \%$, respectively, as reported in the literature. In turn, total fibres constitute $58 \%$ with $4 \mathrm{~g} / 100 \mathrm{~g}$ of the soluble fraction and $54 \mathrm{~g} / 100 \mathrm{~g}$ of the insoluble fraction [11]. Extracts of raw R. suavissimus leaves were reported to contain $11 \%$ of polysaccharides [36]. Sugars detected in $R$. chingii were represented by rhamnose, arabinose, xylose, glucose, and galactose. These bioactive compounds isolated from the leaves of this species exhibited antioxidant, anti-inflammatory, and anti-cancer activity (MCF-7 and Bel7402). Given their bioactivity, these compounds can be a source of food additives [37].

In the present study, polyphenolic compounds were stained with potassium dichromate or iron chloride. In various Rubus species, these compounds have been reported to exhibit antioxidant capacity determined with in vivo and in vitro methods $[11,38]$. The antioxidant group was dominated by caffeic acid, ferulic acid, quercetin, kaempferol, chlorogenic acid, caffeoylquinic acid [38]. The highest total antioxidant activity in the leaves of the analysed $R$. idaeus cultivars determined with the FRAP and Folin-Ciocalteu methods was found for 'Radziejowa' [11]. The concentration of phenolic compounds in the leaf extracts from the different Rubus species was significantly correlated with the antioxidant activity [12, 39]. Szymanowska et al. [40] reported antioxidant and anti-inflammatory properties of phenolic compounds and anthocyanins contained in $R$. idaeus fruit extracts. Their antiinflammatory action was manifested by an inhibitory effect on the activity of 
lipoxygenase and cyclooxygenase- 2 in vitro. These extracts effectively inhibited the viability of human leukaemia cells J45 and HL60 in in vitro investigations of cytotoxic activity. As demonstrated by Manríquez-Torres et al. [41], fruits of various Rubus species exhibited high antioxidant activity due to their content of anthocyanins and other antioxidants.

\subsection{Anatomy}

The epidermis of the examined leaves was formed of large cells with a thick outer wall and a cuticle layer. The palisade parenchyma cells formed two layers. These traits are ecological adaptations to environmental conditions allowing more efficient utilisation of solar radiation [42]. The distribution of mesophyll cells in these leaves and leave of plants from the genera Sorbus and Pyrus described in the literature indicated a bifacial type [21, 43]. A welldeveloped palisade parenchyma determines efficient photosynthesis and is an ecological strategy of adaptation to environmental conditions. This parenchyma utilises solar light more efficiently than the spongy tissue. Plants from insolated habitats are characterised by a welldeveloped palisade parenchyma. In turn, the amount of the spongy parenchyma increases in shaded environments [42].

\subsection{Content of macro- and microelements}

Potassium and calcium followed by magnesium and phosphorus dominated in the leaves of the analysed raspberry cultivars. The content of macro- and microelements in raspberry leaves largely depends on the mode of cultivation and the environment. This is evidenced by the large variation of the quantities of these elements in the leaves of raspberry cultivated in different remote regions of Lublin Province, south-eastern Poland [44]. The results of the $\mathrm{K}, \mathrm{Mg}$, and $\mathrm{P}$ content presented in this study are within the ranges specified by the aforementioned authors for these elements, i.e. K (10600-20500 mg/kg), Mg (2600-4500 $\mathrm{mg} / \mathrm{kg}$ ), and P (1900-3000 mg/kg), in R. idaeus leaves. In turn, the concentration of Ca (2610 - $4800 \mathrm{mg} / \mathrm{kg}$ ) determined in this study is lower than the content of this element (7200-15500 $\mathrm{mg} / \mathrm{kg}$ ) in the raw material collected by these researchers. These mineral elements are components of enzymes and proteins as well as important elements of biochemical processes and tissue structures in the human organism [45].

Assessment of the nutritional value in terms of the content of macro- and microelements in the leaves of the raspberry cultivars analysed in this study can be based on comparison of 
their concentrations in the leaves of different Camelia sinensis cultivars. In comparison with green tea leaves, the $\mathrm{Ca}, \mathrm{Mg}, \mathrm{Cu}, \mathrm{Fe}$, and $\mathrm{Zn}$ content reported in the present study was similar or higher, the amount of $\mathrm{K}$ and $\mathrm{P}$ was in the same range, and the level of $\mathrm{Na}, \mathrm{Pb}$, and $\mathrm{Cd}$ was lower. In turn, the Fe content in the examined $R$. idaeus cultivars was substantially higher than the concentration of this element in Camelia sinensis leaves [46]. Milošević et al. [47] reported that blackberry fertilisation with NPK, manure, natural zeolite, and their mixtures changed a majority of cane and berry physical traits and leaf nutrient status. Increased mesonutrients improve the growth of micropropagated red raspberries. The ratio of ammonium to nitrate varies greatly for improving plant growth. An important step is to determine the driving mineral factors in improved medium formulations for micropropagated red raspberries [48]. The content of $\mathrm{Ca}$ in the in our studies were from half to three fold lower than in leaf blades in $R$. coreanus. In turn, the content of $\mathrm{K}$ was lower in 'Glen Ample', equal in 'Radziejowa' and greater in 'Laszka' than in $R$. coreanus. In leaves 'Glen Ample' and 'Radziejowa' the higher $\mathrm{Mg}$ and $\mathrm{Cu}$ and lower content than in $R$. coreanus was found [12].

The content of trace elements, i.e. cadmium $(0.0007-0.0029 \mathrm{mg} / \mathrm{kg})$ and lead $(0,0018$ 0,0023), in the examined $R$. idaeus leaves was significantly lower than the permissible levels specified for plant raw materials [49]. Lead and cadmium are very harmful to humans [50]. Lead is toxic to the circulatory, nervous, and digestive systems and accumulates in bones [51, 52]. In turn, cadmium damages kidneys, bones, and the respiratory system [53]. The content of $\mathrm{Cd}$ and $\mathrm{Pb}$ in the leaves of the $R$. idaeus cultivars analysed in the present study and described in the literature $(\mathrm{Cd} 0.0026 \mathrm{mg} / \mathrm{kg}, \mathrm{Pb} 0.0018-0.0023 \mathrm{mg} / \mathrm{kg}$ ) is substantially lower than in Camelia sinensis tea leaves (Cd $0.05 \mathrm{mg} / \mathrm{kg}, \mathrm{Pb} 2.28-4.33 \mathrm{mg} / \mathrm{kg}$ ) [46]. This indicates that the raspberry shrubs analysed in this study grow on unpolluted and uncontaminated soil in the clean environment of the Lublin Upland located in the east-south of Poland.

\section{Material and methods}

\subsection{Research material}

Leaves of three Rubus idaeus L. cultivars: 'Glen Ample', 'Laszka', and 'Radziejowa' were collected from shrubs growing in a plantation located in Blinów II, south-eastern Poland (5052'57.03" N; 22²3'2.663" E). Six samples of young, healthy, and well-developed leaves of each cultivar were taken from the fifth node at the onset of plant flowering. The content of micro- and macroelements as well as trace elements was determined in dry plant material. The 
collected leaves were dried in a natural airy drying room protected from solar radiation. Handmade cross sections of fresh leaves were prepared for histological assays and fragments of laminas were sampled and fixed for microscopic observations aimed at comparison of the structure of trichomes and leaf tissues.

\subsection{Fixation of samples and preparation of slides}

Fragments were collected from the central and apical part of fresh leaves and fixed in $4 \%$ glutaraldehyde for 6 hours at room temperature and in $0.1 \mathrm{M}$ phosphate buffer, $\mathrm{pH} 7.0$, at $4^{\circ} \mathrm{C}$ for $48 \mathrm{~h}$. To prepare semi-thin sections, fixed samples were rinsed in phosphate buffer and dehydrated for $15 \mathrm{~min}$ in a series of ethyl alcohol at concentrations of 15, 30, 50, 70, 90, and 96 and twice in absolute ethanol. Dehydrated plant fragments were embedded in Spurr Low Viscosity resin and polymerised at a temperature of $60^{\circ} \mathrm{C}$ for $48 \mathrm{~h}$. Semi-thin cross sections were made from the resin-embedded material. $1-\mu \mathrm{m}$ thick sections were cut with a glass knife using a Reichert Ultracut S microtome and stained with $1 \%$ toluidine blue and $1 \%$ azure II (1:1) at $60^{\circ} \mathrm{C}$ for $5 \mathrm{~min}$. Stained slides were dried after rinsing with distilled water and 5\% ethyl alcohol. Periodic acid-Schiff (PAS) reactions were performed to determine the presence of polysaccharides in the cell walls.

Comparative analyses of the epidermis micromorphology and the structure of trichomes and leaf tissues of the studied cultivars were carried out using bright-field light microscopy (LM), fluorescence microscopy (FM), electron scanning (SEM) microscopy, and.

\subsection{Microscopy}

Fluorescence microscope

Hand-made cross-sections were prepared from fresh leaf material in order to determine groups of compounds contained in the glandular trichomes and analyse the cuticle layer on the surface of the glandular trichomes and epidermis cells. The sections were placed in a drop of a fluorochrome $(0.01 \%$ auramine $\mathrm{O})$ and embedded in a $50 \%$ glycerol solution [54]. Observations were carried out in a Nikon Eclipse 90i fluorescence microscope equipped with an FITC filter (excitation light 465-495 nm) and a barrier filter (wavelength 515-555 $\mathrm{nm})$. 
Bright-field light microscope

Comparative analyses of epidermis cells and assimilation mesophyll in the leaves of the three Rubus idaeus cultivars were carried out on hand-cut and semi-thin preparations. Microscopic observations and photographic documentation were made under a Nikon Eclipse 400 bright-field light microscope.

Scanning electron microscope

After dehydration in an acetone series at concentrations of 15, 30, 50, 70, 90, and 99,5\% (anhydrous acetone was used twice), fixed plant samples were critical-point dried in liquid $\mathrm{CO}_{2}$ in an Emitech $\mathrm{K} 850$ dryer. Next, the samples were coated with gold using an EMITECH K550X sputter coater. Observations of the leaf epidermis surface and photographic documentation were made using a TESCAN VEGA II LMU scanning electron microscope.

Transmission electron microscopy

Fixed leaf fragments were contrasted in a 1.5.\% osmium tetraoxide solution in order to prepare semithin and ultrathin sections. After rinsing with distilled water, $0.5 \%$ aqueous uranyl acetate was applied for 2 hours at room temperature. When double rinsed with distilled water, fragments of nectaries were dehydrated for 15 minutes in a series of the following concentrations of ethyl alcohol: 15, 30, 50, 70, 90, 96, and 99.8\% and twice in absolute ethanol. The dehydrated samples were embedded in Spurr Low Viscosity resin and polymerised at a temperature of $60^{\circ} \mathrm{C}$ for 48 hours. Ultrathin $70-\mathrm{nm}$ thick sections were cut with a glass knife using a microtome Reichert Ultracut S. Next, they were stained or 40 minutes with an $8 \%$ solution of uranyl acetate in $0.5 \%$ acetic acid. When double rinsed with distilled water (10 minutes), Reynolds reagent was applied for 15 minutes [55]. After rinsing with water, the sections were dried. The ultrastructure of the nectary cells was viewed under a high-resolution transmission electron microscope (TEM) FEI, USA Tecnai Spirit $\mathrm{G}^{2}$.

\subsection{Histochemistry}


The main groups of bioactive compounds present in the glandular trichomes in the epidermis of fresh Rubus idaeus 'Laszka' and 'Radziejowa' leaves were stained with relevant histochemical assays using the following chemical compounds: Nadi reagent (naphtol and dimethyl-paraphenylene-diamine) for terpenoids and essential oils [56], Sudan Red 7B [57 ] and Sudan Black B [58] for total lipids, Nile Blue A [59] for neutral and acidic lipids; Lugol's solution for proteins [59], Fehling's reagent [60] for total sugars, PAS reagent [61] for polysaccharides, and iron chloride [62] and potassium dichromate [63] for phenolic compounds.

\subsection{Microanalysis of elements in selected parts of epidermis cells}

The qualitative and quantitative microanalysis of the content of selected macroelements (N, P, K, Na, Ca, Mg, S) and microelements (B, Fe, Zn, Se, Mo, Cd, Pb) in the cuticle and other parts of the cell wall as well as the cytoplasm and vacuoles of the leaf epidermis in Rubus idaeus 'Glen Ample', 'Laszka', and 'Radziejowa' was performed with the use of ultrathin non-contrasted sections (thickness $100 \mathrm{~nm}$ ). The microanalysis was carried out with a high-resolution transmission electron microscope JEM 1400 (JEOL Co., Japan 2008) and a digital microscope controlled from the Windows XP platform and equipped with an X-ray microanalyst (EDS INCA Energy TEM, Oxford Instruments, UK) and a camera 11 Megapixel TEM Morada G2 (EMSIS GmbH, Germany).

\subsection{Determination of elements}

Six samples of young, healthy, and well-developed leaves of each cultivar were taken from the fifth node at the onset of plant flowering. Immediately after sampling, the leaves were dried in a natural airy drying room protected from solar radiation. The dried samples were ground in an analytical mill. 0,5-g aliquots of milled plant samples were transferred to Teflon tubes and $10 \mathrm{~cm}^{3}$ of $\mathrm{HNO}_{3}$ were added. Next, the plant material was mineralised in a CEM Mars Xpress microwave oven at a temperature of $210{ }^{\circ} \mathrm{C}$ and under pressure of 7 atmospheres. The mineralizates were quantitatively transferred into $50-\mathrm{cm}^{3}$ volumetric flasks and diluted with demineralised water (conductivity of $0.055 \mu \mathrm{S} / \mathrm{cm}$ ) to the indicated volume.

The solutions were analysed using a Varian SpectrAA 20FS flame atomic absorption spectrophotometer with the following settings (absorption, slit width, lamp current) for the selected elements, respectively: Ca (422,7 nm; 0,5 nm; $10 \mathrm{~mA}) ; \operatorname{Mg}(202,6 \mathrm{~nm} ; 1 \mathrm{~nm} ; 4 \mathrm{~mA})$; 
Fe (248,3 nm; 0,2 nm; $5 \mathrm{~mA}) ; \mathrm{Cu}(324,8 \mathrm{~nm} ; 0,5 \mathrm{~nm} ; 4 \mathrm{~mA}) ; \mathrm{Zn}(213,9 \mathrm{~nm} ; 1 \mathrm{~nm} ; 5 \mathrm{~mA})$. In turn, the emission and slit width was $589 \mathrm{~nm}$ and $0,2 \mathrm{~nm}$ for $\mathrm{Na}$ and $589 \mathrm{~nm}$ and 0,2 $\mathrm{nm}$ for $\mathrm{K}$, respectively; the HCL lamp was not used for both these elements. A 100-mm slit burner based on a stoichiometric acetylene/air mixture was used as an atomiser. To avoid ionisation of $\mathrm{Ca}_{-}, \mathrm{Mg}-$, $\mathrm{Na}-$, and $\mathrm{K}$-containing samples and to ensure appropriate atomisation conditions, Schinkel spectral buffer $\left(10 \mathrm{~g} / \mathrm{dm}^{3} \mathrm{CsAl}+100 \mathrm{~g} / \mathrm{dm}^{3} \mathrm{La}\right)$ was used at a level of $10 \%$ of the sample dose.

To determine $\mathrm{Pb}$ and $\mathrm{Cd}$, the solutions were analysed using an inductively coupled plasma mass spectrophotometer (ICP Mass Spectrometer Varian MS - 820). Argon with a purity of $99.999 \%$ was the plasma-forming gas. No reaction chamber (CRI) was used in the analysis. The following parameters were adopted: plasma flow $-16 \mathrm{dm}^{3} / \mathrm{min}$, nebuliser flow $0,98 \mathrm{dm} 3 / \mathrm{min}$, RF power - 1,38 kW, sampling depth - 6,5 mm; ${ }^{114} \mathrm{Cd},{ }^{206} \mathrm{~Pb},{ }^{207} \mathrm{~Pb}$, and ${ }^{208} \mathrm{~Pb}$ isotopes were used.

The determination was carried out with the standard curve method with deuteriumlamp background correction. Ultra Scientific standards with a purity of $99.999 \%$ were used for the analysis.

\subsection{Determination of phosphorus}

The content of total phosphorus in air-dry leaves of the three $R$. idaeus cultivars was determined with the spectrophotometric method in accordance with the PN-ISO 6491:2000 standard. Samples of ground plant material $(2.5 \mathrm{~g})$ were mixed with $1 \mathrm{~g}$ of calcium carbonate and incinerated in an electric muffle furnace at $550^{\circ} \mathrm{C}$. The ash was transferred to a $250-\mathrm{ml}$ beaker with 20-50 $\mathrm{ml}$ of water. Hydrochloric acid was added until effervescence ceased and additional $10 \mathrm{ml}$ of hydrochloric acid was added. The beaker was placed in a sand bath and evaporated to dryness to obtain an insoluble silica form. After cooling and addition of $10 \mathrm{ml}$ of nitric acid (V), the residue was boiled for 5 minutes in the sand bath. The liquid was transferred to a 500-ml volumetric flask and filtered. A filtrate aliquot was diluted with water to obtain a solution with a concentration not exceeding $40 \mu \mathrm{g} / \mathrm{ml} .10 \mathrm{ml}$ of the solution were transferred to a test tube with addition of $10 \mathrm{ml}$ of vanadate-molybdate reagent. A portion of the solution was transferred to a measuring cuvette and absorbance was measured spectrophotometrically at a wavelength of $430 \mathrm{~nm}$ against a reference solution. A calibration curve was made by plotting absorbance against the corresponding concentrations of standard phosphorus solutions. 


\subsection{Morphometric analyses}

The length and width as well as the surface area of the secretory head and stalk of glandular trichomes were measured in the adaxial epidermis of the leaves from the three cultivars. In the abaxial epidermis, the size of stomata, i.e. their length and width, as well as the thickness of the cuticular ledge and the length of the groove between the cuticular ledges were compared. The height and width of epidermal cells as well as the size of palisade parenchyma cells in the subcuticular layer were measured on both surfaces of the leaf epidermis in the examined cultivars. The thickness of the lamina and the palisade and spongy parenchyma were compared. The morphometric measurements of the epidermis and tissue structures were performed using a computer program for microscopic image analysis Nikon NIS-Elements version 3.0 Advance Research.

\subsection{Statistical analysis of the research results}

Morphometric measurements of the trichomes and leaf tissues were carried out in 20 replicates and the content of the selected elements was determined in four replicates in the three cultivars. The mean values of the measurements and determinations and the standard deviation were calculated with the Microsoft Excel 2013 Program. The significance of differences between the cells of the analysed tissues was analysed statistically with the use of Statistica 6.0 software. The differences between the traits were evaluated with one-way analysis of variance ANOVA. Statistical inference was carried out at the significance level of $\mathrm{P}<0.05$.

\section{Conclusions}

The glandular trichomes with a multicellular head and a multilayer stalk were present on the epidermis in 'Laszka' and 'Radziejowa'. The micromorphology of the abaxial $R$. idaeus epidermis exhibited a striated or smooth cuticle, stomata located above the other epidermis cells, and characteristic long, twisted non-glandular trichomes. The densely growing non-glandular trichomes may have a relaxing function, preventing clumping of mixed raw materials in herbal mixtures. The groups of bioactive compounds: polyphenols, terpenes, lipids, proteins, and carbohydrates were identified in the $R$. ideaus glandular 
trichomes using histochemical assays. Given the bioactivity as well as antimicrobial and antioxidant activity of the compounds, the leaves of this species can be a source of bioactive compounds. The $R$. idaeus leaves are classified as hypostomatic and bifacial. N, Na, S, Ca, and $\mathrm{Mg}$ were the dominant macroelements in the epidermis cells of $R$. idaeus leaves at the level of the ultrastructure of the cuticle and in the other parts of the cell wall, cytoplasm, and vacuole. B, Mo, and Se were the dominant microelements. $\mathrm{K}, \mathrm{Mg}, \mathrm{Ca}, \mathrm{P}$, and $\mathrm{Fe}$ were the dominant elements in the leaves of the analysed cultivars. Infusions from raspberry leaves are safe for health in terms of the $\mathrm{Cd}$ and $\mathrm{Pb}$ concentrations, well below the permissible level. Raspberry leaves can be a valuable raw material for preparation of infusions due to the high content of macro- and microelements.

Author Contributions: Conceptualization, M.Ch.; Data curation, M.Ch and M.K.; Formal analysis, M.Ch and M.K.; Investigation, M.Ch and M.K.; Methodology, M.Ch and M.K.; microscopic observations, M.Ch; Writing-original draft, M.Ch; Writing-review \& editing, M.Ch.

\section{Acknowledgements}

The research was supported by the Ministry of Science and Higher Education of Poland in part of the statutory activities of University of Life Sciences in Lublin.

\section{Conflicts of interest}

The authors declare no conflicts of interest.

\section{References}

1. Naruhashi, N.; Iwatsubo, Y.; Peng, C.I. Chromosome numbers in Rubus (Rosaceae) of Taiwan. Bot. Bull. Acad. Sin. 2002, 43, 193-201.

2. Miyashita, T.; Kunitake, H.; Yotsukura, N.; Hoshino, Y. Assessment of genetic relationships among cultivated and wild Rubus accessions using AFLP markers. Sci. Hortic. 2015, 193, 165-173. doi:10.1016/j.scienta.2015.07.004

3. Finn, C.E.; Moore, P.P.; Kempler, C. Rasberry cultivars: what's new? What's succeeding? Where are breeding programs heading? Acta Hort. 2005, 777, 33-40. 
4. Ali, L.; Svensson, B.; Alsanius, B.W.; Olsson, M.E. Late season harvest and storage of Rubus berries - major antioxidant and sugar levels. Sci. Hortic. 2011, 129, 376-381. doi:10.1016/j.scienta.2011.03.047

5. Konopiński, M.; Żuber, S. Response of raspberry (Rubus idaeus L.) on soil mulching and foliar nutrition with manganese. Mod. Phytomorph. 2013, 3, 119-124. doi:10.5281/zenodo. 162000

6. Ribeiro, R.D.A.; De Melo, M.M.R.F.; De Barros, F.; Gomes, C.; Trolin, G. Acute antihypertensive effect in conscious rats produced by some medicinal plants used in the state of Sao Paulo. J. Ethnopharmacol. 1986, 15, 261-269. doi.org/10.1016/03788741(86)90164-9

7. Tomczyk, M.; Gudej, J. Polyphenolic compounds from Rubus saxatilis. Chem. Nat. Compd. 2005, 41, 349-351.

8. Gallaher, R.N.; Gallaher, K.; Marshall, A.J.; Marshall, A.C. Mineral analysis of ten types of comercially available tea. J. Food Compos. Anal. 2006, 19, S53-S57. doi.org/10.1016/j.jfca.2006.02.006

9. Grabek-Lejko, D.; Wojtowicz, K. Comparison of antibacterial and antioxidant properties of fruits and leaves of blackberry (Rubus plicatus) and raspberry (Rubus idaeus L.). J. Microbiol. Biotechnol. Food Sci. 2014, 3, 514-518.

10. Costea, T.; Vlase, L.; Gostin, I.N.; Olah, N.K.; Predan, G.M. Botanical characterization, phytochemical and antioxidant activityof indogenous red raspberry (Rubus idaeus L.) leaves. Studia Univ. VG, SSV. 2016, 26, 463-472.

11. Chwil, M.; Kostryco, M. Bioactive compounds and antioxidant activity of Rubus idaeus L. leaves. Acta Sci. Pol. Hortorum Cultus. 2018, 17, 135-148. doi: 10.24326/asphc.2018.2.12

12. Om, A.S.; Song, Y.N.; Noh, G.; Kim, H.; Choe, J. Nutrition composition and single, 14-day and 13-week repeated oral dose toxicity studies of the leaves and stems of Rubus coreanus Miquel. Molecules 2016, 21, 65. doi.org/10.3390/molecules21010065

13. Buřričová, L.; Andjelkovic, M.; Čermáková, A.; Zuzana, R.; Ondřej, J.; Kolehmainen, E.; Verhé, R.; Kvasnička, F. Antioxidant capacities and antioxidants of strawberry, blackberry and raspberry leaves. Czech J. Food Sci. 2011, 29, 181-189.

14. Aybastıer, Ö.; Işık, E.; Şahin, S.; Demir, C. Optimization of ultrasonic-assisted extraction of antioxidant compounds from blackberry leaves using response surface methodology. Ind. Crops Prod. 2013, 44, 558-565. doi.org/10.1016/j.indcrop.2012.09.022 
15. Ścibior, D.; Czeczot, H. Katalaza - budowa, właściwości, funkcje. [Catalase: structure, properties, functions]. Postępy Hig. Med. Dośw. 2006, 60, 170-180.

16. Romanowicz, A.; Krzepiłko, A. Porównanie aktywności katalazy w różnych organach maliny powtarzającej Rubus idaeus L. odmiany Polana oraz w glebie pod jej uprawą, oznaczanej metodą wolumetryczną. [Comparison of catalase activity in various organs of Rubus idaeus L. raspberry cv Polana and in soil under cultivation thereof determined with the volumetric method]. Pol. J. Agron. 2013, 15, 49-53.

17. Tomaszewski, D.; Zieliński, J.; Gawlak, M. Foliar indumentum in central-European Rubus species (Rosaceae) and its contribution to the systematics of the group. Nord. J. Bot. 2014, 32, 1-10. doi.org/10.1111/j.1756-1051.2013.00116.x

18. Upadhyaya, M.K.; Furness, N.H. Primocane morphology and leaf surface characteristics of greenhouse-grown red raspberry cultivars. Hort. Sci. 1998, 33, 330332.

19. Karley, A.J.; Mitchell, C.; Brookes, C.; McNicol, J.; O’Neill, T.; Roberts, H.; Graham, J.; Johnson, S.N. Exploiting physical defence traits for crop protection: leaf trichomes of Rubus idaeus have deterrent effects on spider mites but not aphids. Ann. Appl. Biol. 2015, 168, 159-172. doi.org/10.1111/aab.12252

20. Schreiber, L.; Bach, S.; Kirsch, T.; Knoll, D.; Schalz, K.; Riederer, M. A simple photometric device analysing cuticular transport physiology: surfactant effect on permeability of isolated cuticular membranes of Prunus laurocerasus L. J. Exp. Bot. 1995, 46, 1915-1921. doi.org/10.1093/jxb/46.12.1915

21. Krivoruchko, O.V.; Gamulya, O.V. The anatomical study of Sorbus aucuparia and Sorbus domestica leaves. News Pharm. 2013, 4, 33-36.

22. Song, J.H.; Hong, S.P. The taxonomic implication of leaf anatomy in tribe Sorbarieae (Spiraeoideae: Rosaceae). Korean J. Pl. Taxon. 2014, 44, 119-131. Doi: 10.11110/kjpt.2014.44.2.11

23. Jaliseh, S.A.; Mehregan, I.; Tarang, A.; Nejadsattari, T. Genetic diversity of Rubus L. (Rosaceae) in the Northern Iran. Bull. Georgian Natl. Acad. Sci. 2015, 9, 387-394.

24. Levin, D.A. The role of trichomes in plant defense. Q. Rev. Biol. 1973, 48, 3-15.

25. Wilkens, T.; Shea, G.O.; Halbreich, S.; Stamp, N.E. Resource availability and the trichome defenses of tomato plants. Oecologia. 1996, 106, 181-191.

26. Graham, J.; Hackett, C.A.; Smith, K.; Karley, A.J.; Mitchell, C.; Roberts, H.; O’Neill, T. Genetic and environmental regulation of plant architectural traits and opportunities 
for pest control in raspberry. Ann. Appl. Biol. 2014, 165, 318-328. doi.org/10.1111/aab.12134

27. Chou, G.; Xu, S.J.; Liu, D.; Koh, G.Y.; Zhang, J.; Liu, Z. Quantitative and fingerprint analyses of Chinese sweet tea plant (Rubus suavissimus S. Lee). J. Agric. Food Chem. 2009, 57, 1076-1083. doi: 10.1021/jf8029397

28. Chou, W.H.; Oinaka, T.; Kanamaru, F.; Mizutani, K.; Chen, F.H.; Tanaka, O. Diterpene glycosides from leaves of Chinese Rubus chingii and fruits of $R$. suavissimus, and identification of the source plant of the Chinese folk medicine "Fupen-zi”. Chem. Pharm. Bull. 1987, 35, 3021-3024. doi.org/10.1248/cpb.35.3021

29. Shepherd, T.; Robertson, G.W.; Griffiths, D.W.; Birch, A.N.E. Epicuticular wax ester and triacylglycerol composition in relation to aphid infestation and resistance in red raspberry (Rubus idaeus L.). Phytochemistry. 1999, 52, 1255-1267. doi.org/10.1016/S0031-9422(99)00414-8

30. Colditz, F.; Niehaus, K.; Krajinski, F. Silencing of PR-10-like proteins in Medicago truncatula results in an antagonistic induction of other PR proteins and in an increased tolerance upon infection with the oomycete Aphanomyces euteiches. Planta. 2007, 226, 57-71.

31. Hukkanen, A.; Kokko, H.; Buchala, A.; Häyrinen, J.; Kärenlampi, S. Benzothiadiazole affects the leaf proteome in arctic bramble (Rubus arcticus). Mol. Plant Pathol. 2008, 9, 6, 799-808. doi.org/10.1111/j.1364-3703.2008.00502.x

32. De Nardi, B.; Dreos, R.; Del Terra, L.; Martellossi, C.; Asquini, E.; Tornincasa, P.; Gasperini, D.; Pacchioni, B.; Rathinavelu, R.; Pallavicini, A.; Graziosi, G. Differential responses of Coffea arabica L. leaves and roots to chemically induced systemic acquired resistance. Genome. 2006, 49, 1594-1605. doi.org/10.1139/g06-125

33. Fernandes, H.; Pasternak, O.; Bujacz, G.; Bujacz, A.; Sikorski, M.M.; Jaskolski, M. Lupinus luteus pathogenesis-related protein as a reservoir for cytokinin. J. Mol. Biol. 2008, 378, 1040-1051. doi.org/10.1016/j.jmb.2008.03.027

34. Mogensen, J.E.; Ferreras, M.; Wimmer, R.; Petersen, S.V.; Enghild, J.J.; Otzen, D.E. The major allergen from birch tree pollen, Bet $\mathrm{v} 1$, binds and permeabilizes membranes. Biochemistry 2007, 46, 3356-3365. doi:10.1021/bi062058h

35. Hjernø, K.; Alm, R.; Canbäck, B.; Matthiesen, R.; Trajkovski, K.; Björk, L.; Roepstorff, P.; Emanuelsson, C. Down-regulation of the strawberry Bet v 1homologous allergen in concert with the flavonoid biosynthesis pathway in colorless strawberry mutant. Proteomics 2006, 6, 1574-1587. doi.org/10.1002/pmic.200500469 
36. Koh, G.Y.; Chou, G.; Liu, Z. Purification of a water extract of Chinese sweet tea plant (Rubus suavissimus S. Lee) by alcohol precipitation. J. Agric. Food Chem. 2009, 57, 5000-5006. doi: 10.1021/jf900269r

37. Zhang, T.T.; Lu, C.L.; Jiang, J.G.; Wang, M.; Wang, D.M.; Zhu, W. Bioactivities and extraction optimization of crude polysaccharides from the fruits and leaves of Rubus chingii Hu. Carbohydr. Polym. 2015, 130, 307-315. doi.org/10.1016/j.carbpol.2015.05.012

38. Dall'Acqua, S.; Cervellati, R.; Loi, M.C.; Innocenti, G. Evaluation of in vitro antioxidant properties of some traditional Sardinian medicinal plants: investigation of the high antioxidant capacity of Rubus ulmifolius. Food Chem. 2008, 106, 745-749. doi.org/10.1016/j.foodchem.2007.06.055

39. Oszmiański, J.; Wojdyło, A.; Nowicka, P.; Teleszko, M.; Cebulak, T.; Wolanin, M. Determination of phenolic compounds and antioxidant activity in leaves from wild Rubus L. species. Molecules 2015, 20, 3, 4951-4966. doi:10.3390/molecules20034951

40. Szymanowska, U.; Baraniak, B.; Bogucka-Kocka, A. Antioxidant, anti-inflammatory, and postulated cytotoxic activity of phenolic and anthocyanin-rich fractions from Polana raspberry (Rubus idaeus L.) fruit and juice - In vitro study. Molecules, 2018, 23, 1812. doi.org/10.3390/molecules23071812

41. Manríquez-Torres, J.D.J.; Sánchez-Franco, J.A.; Ramírez-Moreno, E.; Cruz-Cansino, N.D.S.; Ariza-Ortega, J.A.; Torres-Valencia, J.M. Effect of thermoultrasound on the antioxidant compounds and fatty acid profile of blackberry (Rubus fruticosus spp.) Juice. Molecules, 2016, 21, 12, 1624. doi:10.3390/molecules21121624

42. Mohammed, G.H; Noland, T.L.; Irving, D.; Sampson, P.H.; Zarco-Tejada, P.J.; Miller, J.R. Natural and stress-induced effects on leaf spectral reflectance in Ontario species. Forest Research Report 2000, 156; pp. 1 - 34; ISBN 0-7778-9387-8.

43. Zamani, A.; Attar, F.; Ghahreman, A.; Maroofi, H. Anatomical studies of genus Pyrus L. (Rosaceae) in Iran. Iran. J. Bot. 2008, 14, 132-143.

44. Dresler, S.; Bednarek, W.; Tkaczyk, P.; Hawrylak-Nowak, B. Estimation of the macro- and micronutrient status of raspberries grown in the Lublin region. Folia Hort. 2015, 27, 53-62. doi: 10.1515/fhort-2015-0014

45. Higdon, J.; An evidence - based approach to vitamins and minerals. Health implications and intake recommendations. Thieme, New York, Stuttgart, 2003; pp. 253; ISBN 0-58890-124-6. 
46. Chen, Y.; Yu, M.; Xu, J.; Chen, X.; Shi, J. Differentiation of eight tea (Camellia sinensis) cultivars in China by elemental fingerprint of their leaves. J. Sci. Food Agric. 2009, 89, 2350-2355. doi.org/10.1002/jsfa.3716

47. Milošević, T.M.; Glišić, I.P.; Glišić, I.S.; Milošević, N.T. Cane properties, yield, berry quality attributes and leaf nutrient composition of blackberry as affected by different fertilization regimes. Sci. Hortic. 2018, 227, 48-56. doi.org/10.1016/j.scienta.2017.09.013

48. Poothong, S.; Reed, B.M. Modeling the effects of mineral nutrition for improving growth and development of micropropagated red raspberries. Sci. Hortic. 2014, 165, 132-141. doi.org/10.1016/j.scienta.2013.10.040

49. Wang, Z.; Zeng, X.; Geng, M., Chen, C.; Cai, J.; Yu, X.; Hou, Y.; Zhang, H. Health risks of heavy metals uptake by crops grown in a sewage irrigation area in China. Pol. J. Environ. Stud. 2015, 24, 1379-1386. doi: 10.15244/pjoes/35282

50. Grytsyuk, N.; Arapis, G.; Perepelyatnikova, L.; Ivanova, T.; Vynograds'ka, V. Heavy metals effects on forage crops yields and estimation of elements accumulation in plants as affected by soil. Sci. Total Envinron. 2006, 354, 224-231. doi.org/10.1016/j.scitotenv.2005.01.007

51. Glenn, B.S.; Stewart, W.F.; Schwartz, B.S.; Bressler, J. Relation of alleles of the sodium-potassium adenosine triphosphate alpha two gene with blood pressure and lead exposure. Am. J. Epidemiol. 2001, 153, 537-545. doi.org/10.1093/aje/153.6.537

52. Gidlow, D.A. Lead toxicity. Occup. Med. 2004, 54, 76-81.doi.org/10.1590/S167704202005000100004

53. Godt, J.; Scheidig, F.; Grosse-Siestrup, C.; Esche, V.; Brandenburg, P.; Reich, A.; Groneberg, D.A. The toxicity of cadmium and resulting hazard for human health. $J$. Occup. Med. Toxicol. 2006, 1, 1-6. doi.org/10.1186/1745-6673-1-22

54. Heslop-Harrison, Y.; Shivanna, K.R. The receptive surface of the Angiosperm stigma. Ann. Bot. 1977, 41, 1233-1258. doi.org/10.1093/oxfordjournals.aob.a085414

55. Reynolds, R.S. The use of lead citrate at high $\mathrm{pH}$ as electron - opaque stain in electron microscopy. J. Cell Biol. 1963, 17, 208-213.

56. David, R.; Carde, J.P. Coloration dieÂrentielle des pseudophylles de Pin maritime au moyen du reÂactif de Nadi. Comptes Rendus Acad. Sci. Paris, SeÂrie D 1964, 258, $1338-1340$. 
57. Brundrett, M.C.; Kendrick, B.; Peterson, C.A. Efficient lipid staining in plant material with Sudan Red 7B or Fluoral Yellow 088 in polyethylene glycol-glycerol. Biotech. Histochem. 1991, 66, 111-116.

58. Lison, L. Principes et méthodes. in histochimie et cytochimie animales. GauthierVillars, Paris. 1960, 745-746.

59. Jensen, W.A. Botanical histochemistry: Principles and Practice. Freeman, William and Jensen, San Francisco. 1962.

60. Ayoola, G.A.; Coker, H.A.; Adesegun, S.A.; Adepoju-Bello, A.A.; Obaweya, K.; Ezennia, E.C.; Atangbayila, T.O. Phytochemical screening and antioxidant activities of some selected medicinal plants used for malaria therapy in Southwestern Nigeria. Trop. J. Pharm. Res. 20087, 1019-1024. doi.org/10.4314/tjpr.v7i3.14686

61. Feder, N.; O'brien, T.P. Plant microtechnique: some principles and new methods. Am. J. Bot. 1968, 55, 123-142.

62. Johansen, D.A. Plant microtechique. McGraw-Hill Book Company, Inc. London 1940.

63. Gabe, M. Techniques histologiques. Masson, Paris 1968. 

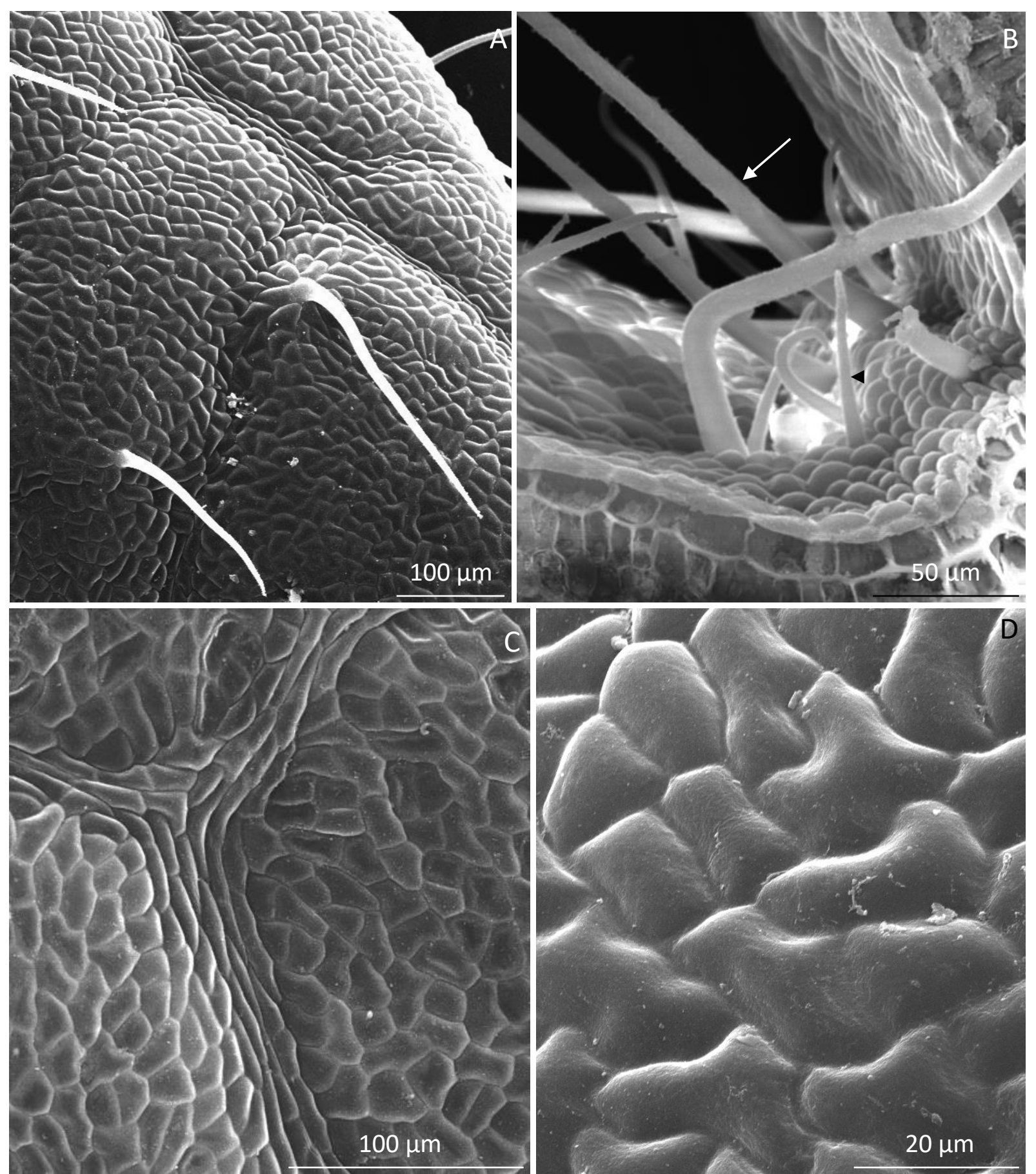

Figure 1A - D. Fragments of the adaxial epidermis surface in the leaves of $R$. idaeus 'Glen Ample': A - non-glandular trichomes on the epidermis surface; B - surface of the midrib, visible unicellular non-glandular trichomes varied in length: short (arrowhead) and long (double arrowhead); C, D - smooth cuticle on the epidermis surface. 

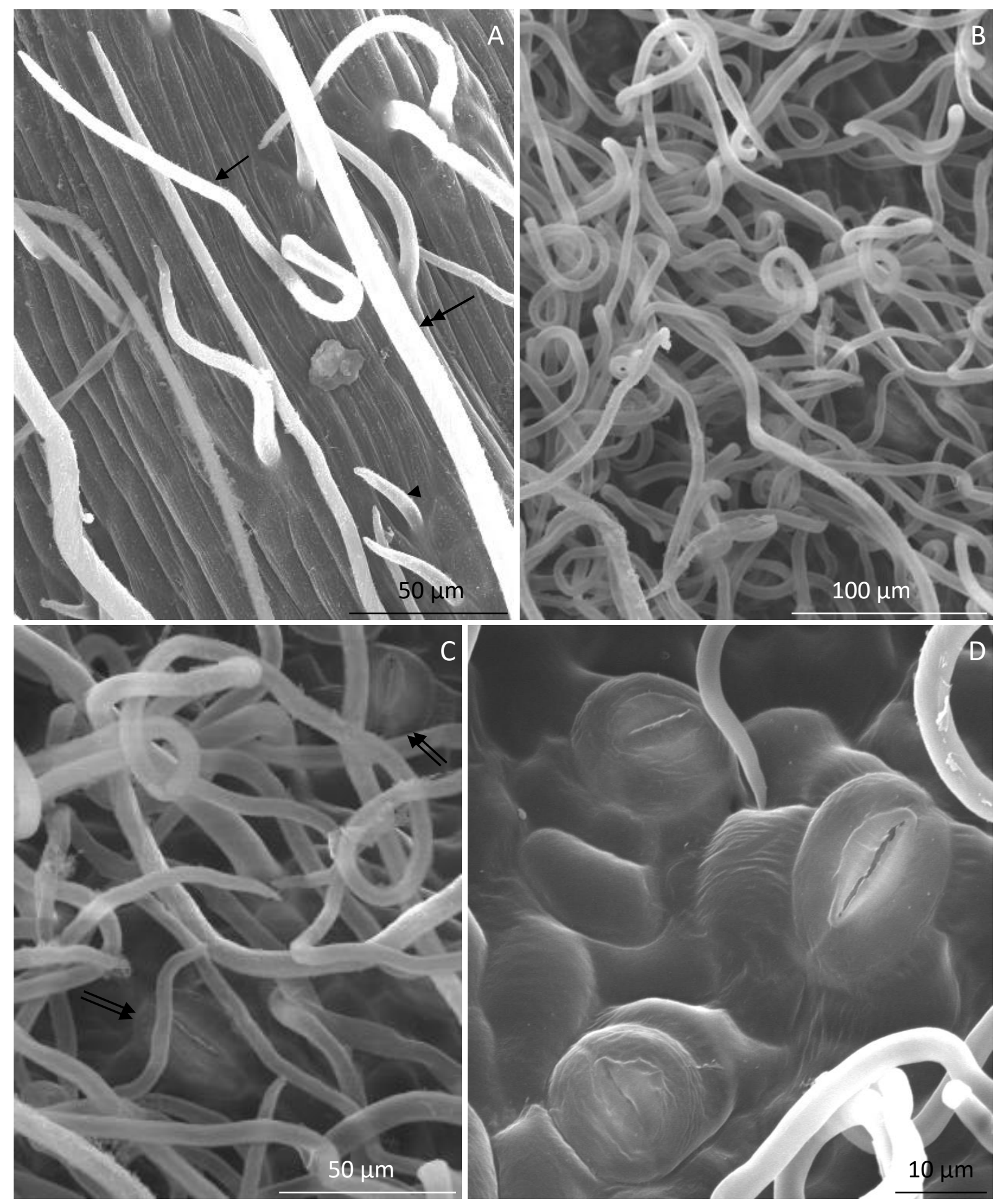

Figure 2A - D. Fragments of the abaxial epidermis surface in the leaves of $R$. idaeus 'Glen Ample': A - sparse non-glandular trichomes on the surface of the midrib: short (arrowhead), medium length (arrow), and long (double arrowhead), visible striated cuticle on the surface of epidermis cells; B, C - densely growing long and twisted non-glandular trichomes, visible stomata (double arrows) (C); D - stomata, visible striated or smooth cuticle on the surface of epidermis cells, thick cuticular ledges. 


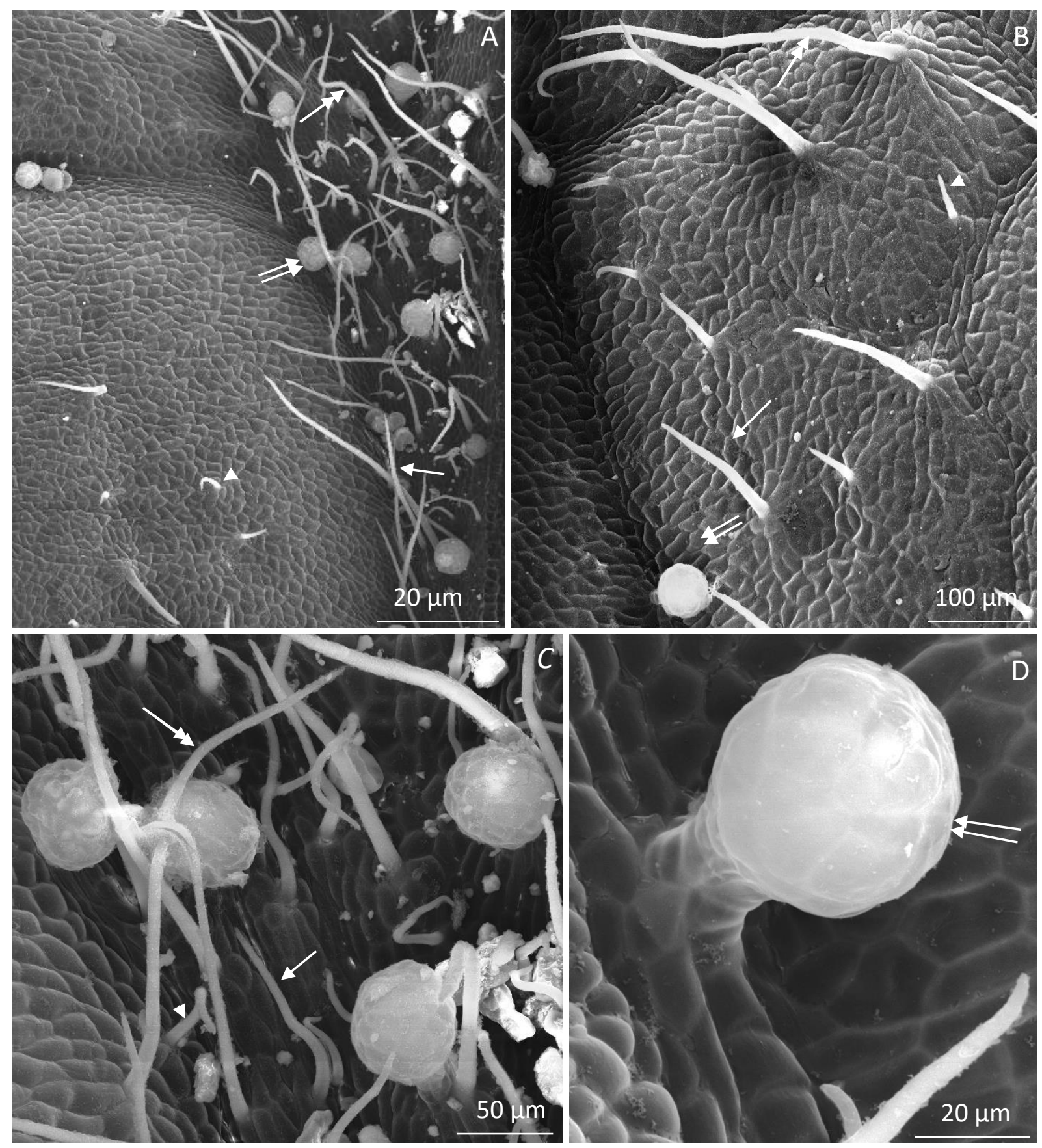

Figure 3A - D. Fragments of the adaxial epidermis surface in the leaves of $R$. idaeus 'Laszka': A, B - non-glandular trichomes: short (arrowhead), medium length (arrow), and long (double arrowhead), visible numerous glandular trichomes on the surface of the midrib (double arrows) (A) and less dense trichomes on other branching veins (B); C - glandular trichomes with a multicellular head (double arrows), visible non-glandular trichomes on the surface of the midrib: short (arrowhead), medium length (arrow), and long (double arrowhead); D glandular trichome with a multicellular, two-layered stalk (in the outline) and a spherical head (double arrows), visible smooth cuticle on the epidermis surface. 


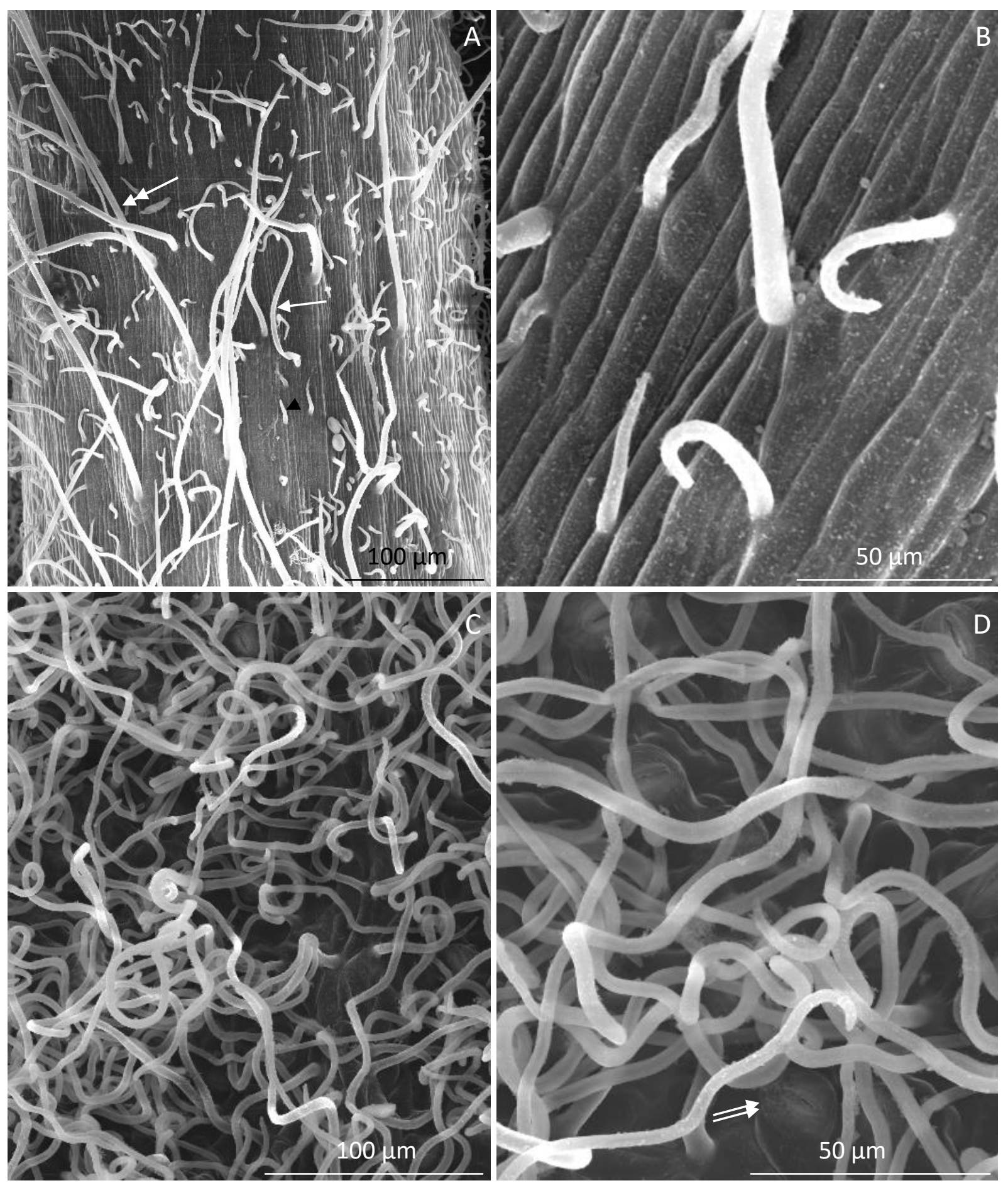

Figure 4A - D. Fragments of the abaxial epidermis surface in the leaves of $R$. idaeus 'Laszka': A, B - surface of the midrib, visible sparse non-glandular trichomes: short (arrowhead), medium length (arrow), and long (double arrowhead), visible striated cuticle on the surface of epidermis cells (B); C - long, twisted non-glandular trichomes masking the epidermis surface; D - long, bent non-glandular trichomes, stomata (double arrows) located at the level or above epidermis cells. 

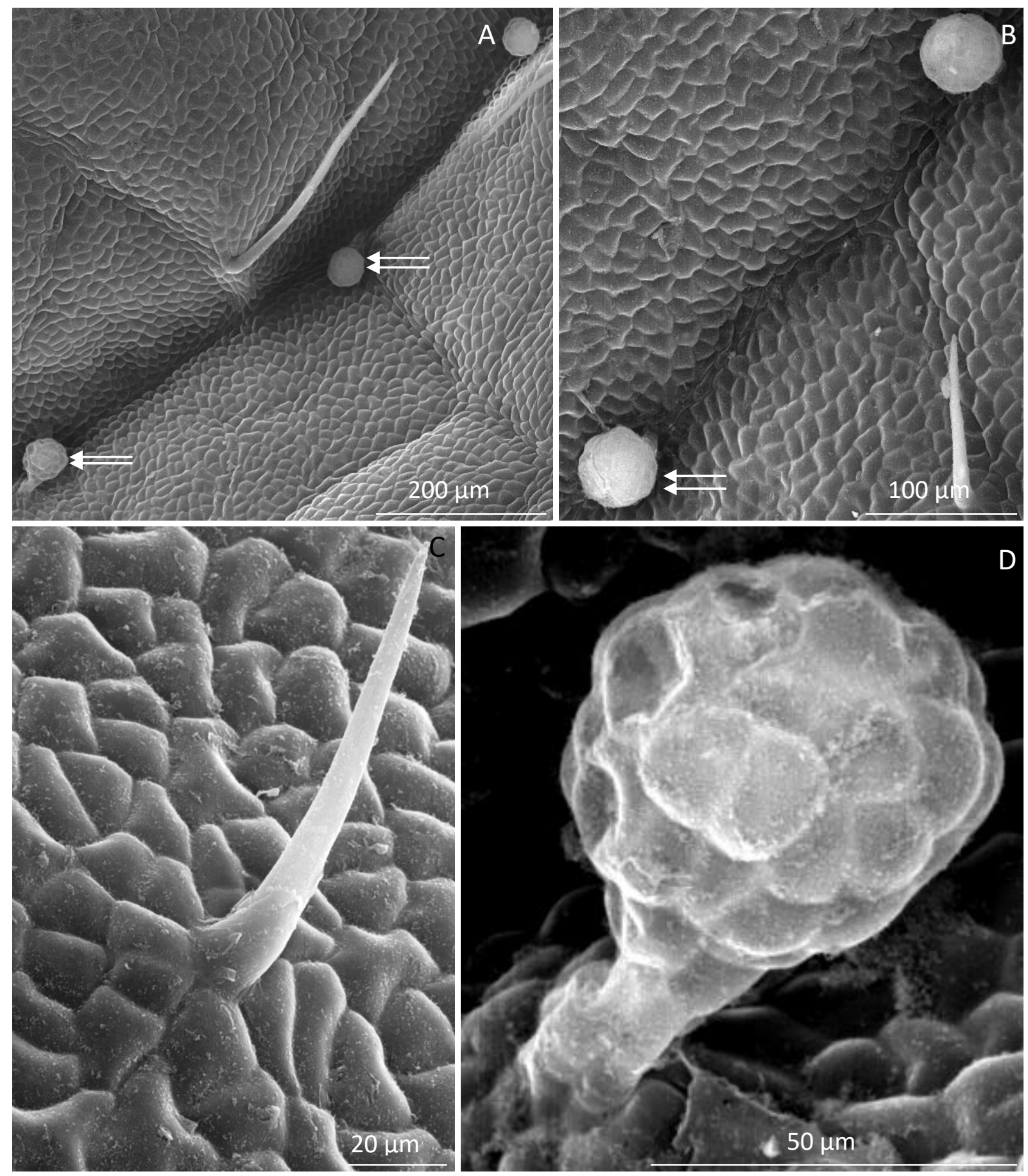

Figure 5A - D. Fragments of the adaxial epidermis surface in the leaves of $R$. idaeus 'Radziejowa': A, B - non-glandular and glandular trichomes (double arrows) growing on the surface of the midrib; C - unicellular non-glandular trichome, smooth cuticle with a wax coating; D - glandular trichome with a multicellular, two-layered stalk (in the outline) and a multicellular head. 


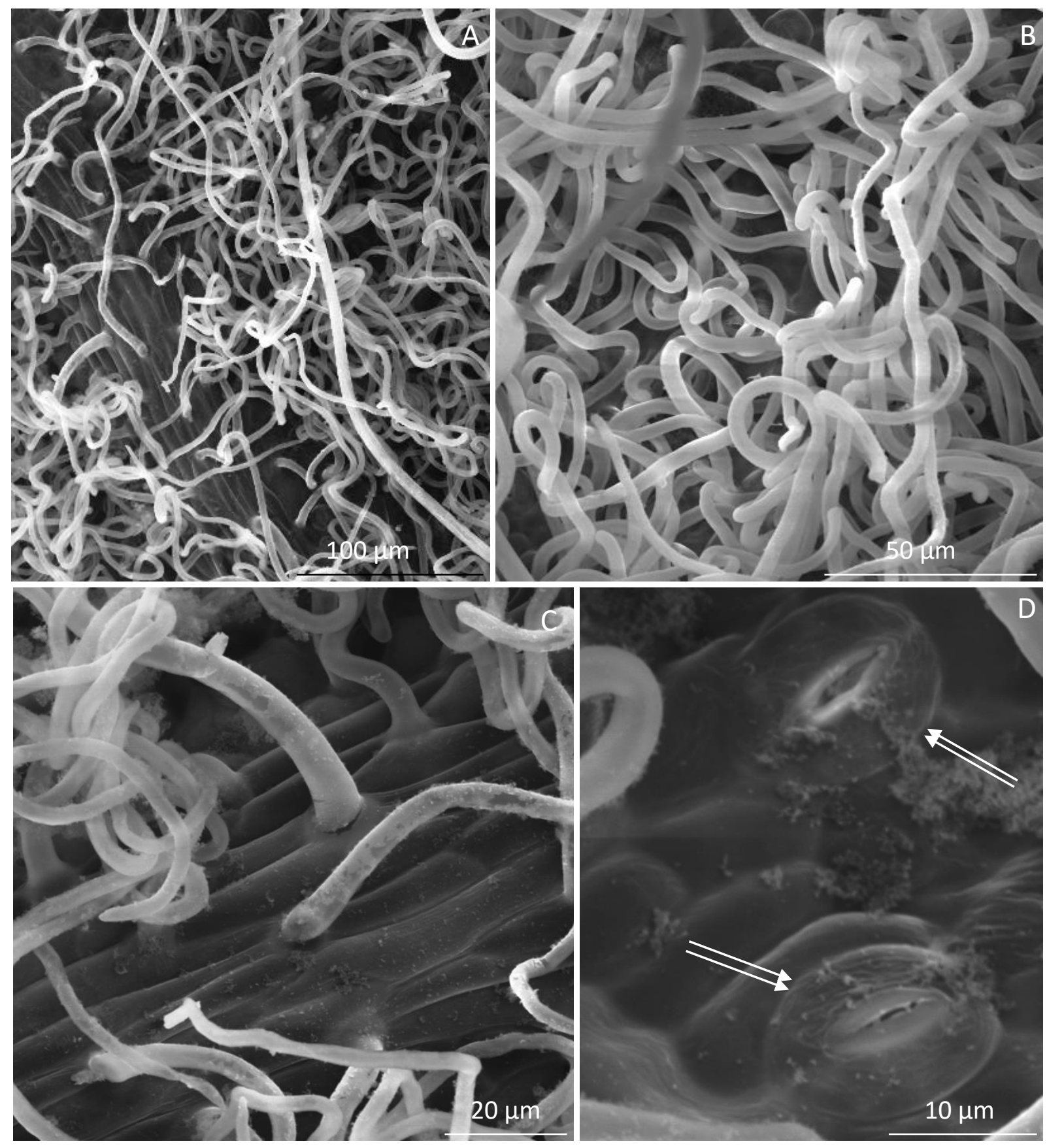

Figure 6. A - D. Fragments of the abaxial epidermis surface in the R. idaeus 'Radziejowa' leaves: A, B

- dense, twisted non-glandular trichomes; C - surface of the midrib; D - stomata (double arrows), visible striated cuticle on the surface of stomatal cells and a smooth or striated cuticle on the surface of other epidermis cells. 

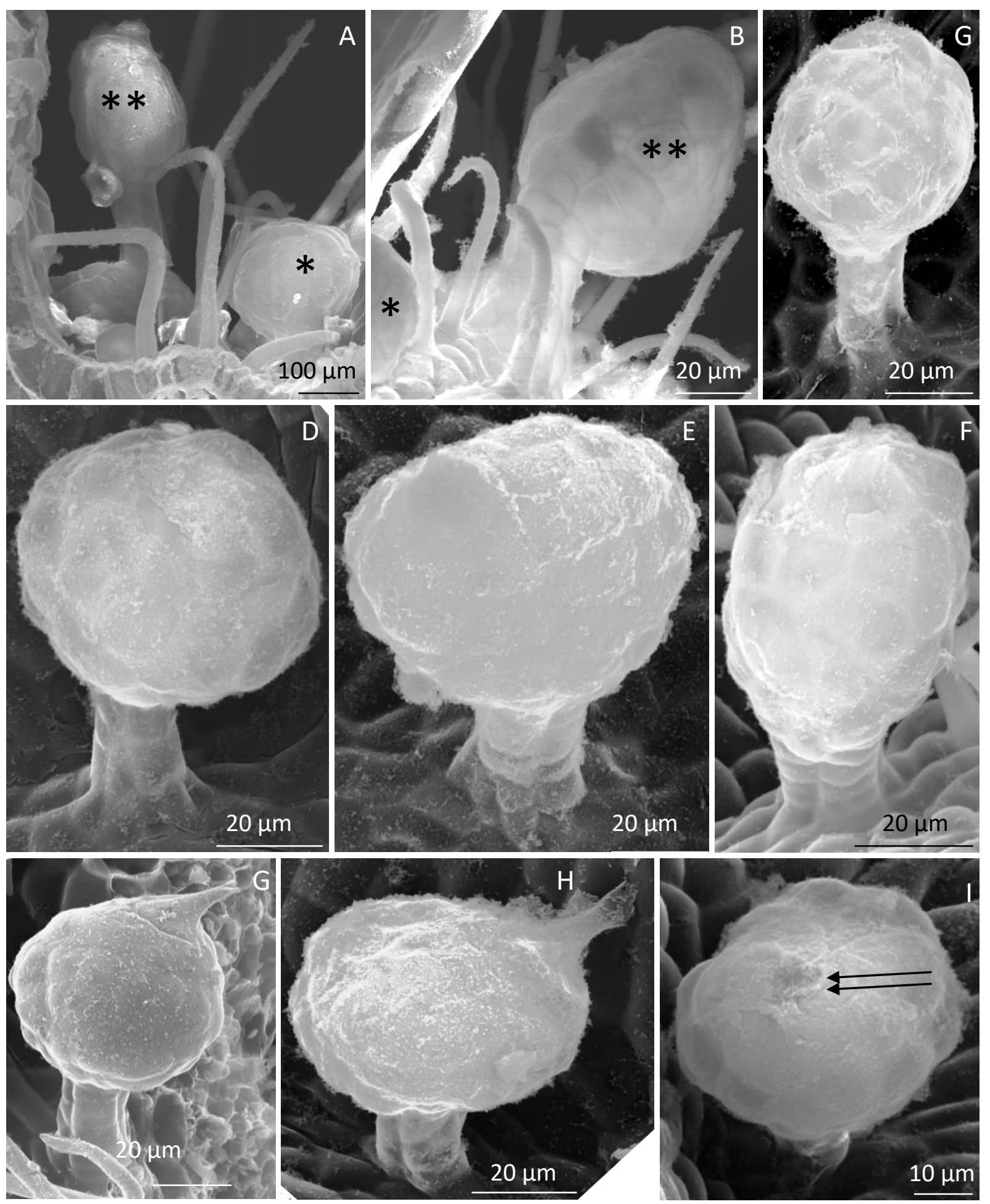

Figure 7A - I. Glandular trichomes in the epidermis of $R$. idaeus 'Laszka' and 'Radziejowa' leaves: A, B - glandular trichomes in the epidermis of the midrib, visible spherical (asterisk) and elliptical (double asterisk) head; C - glandular trichome with a short stalk and a multicellular head; D - F - glandular trichomes, visible two-layered stalk and a spherical (D, E) and elliptical (F) multicellular head; G, H - conical cuticle ruptured at the apex by accumulating secretion; Ispherical secretory head with a visible apical cuticle thickness (double arrows). 


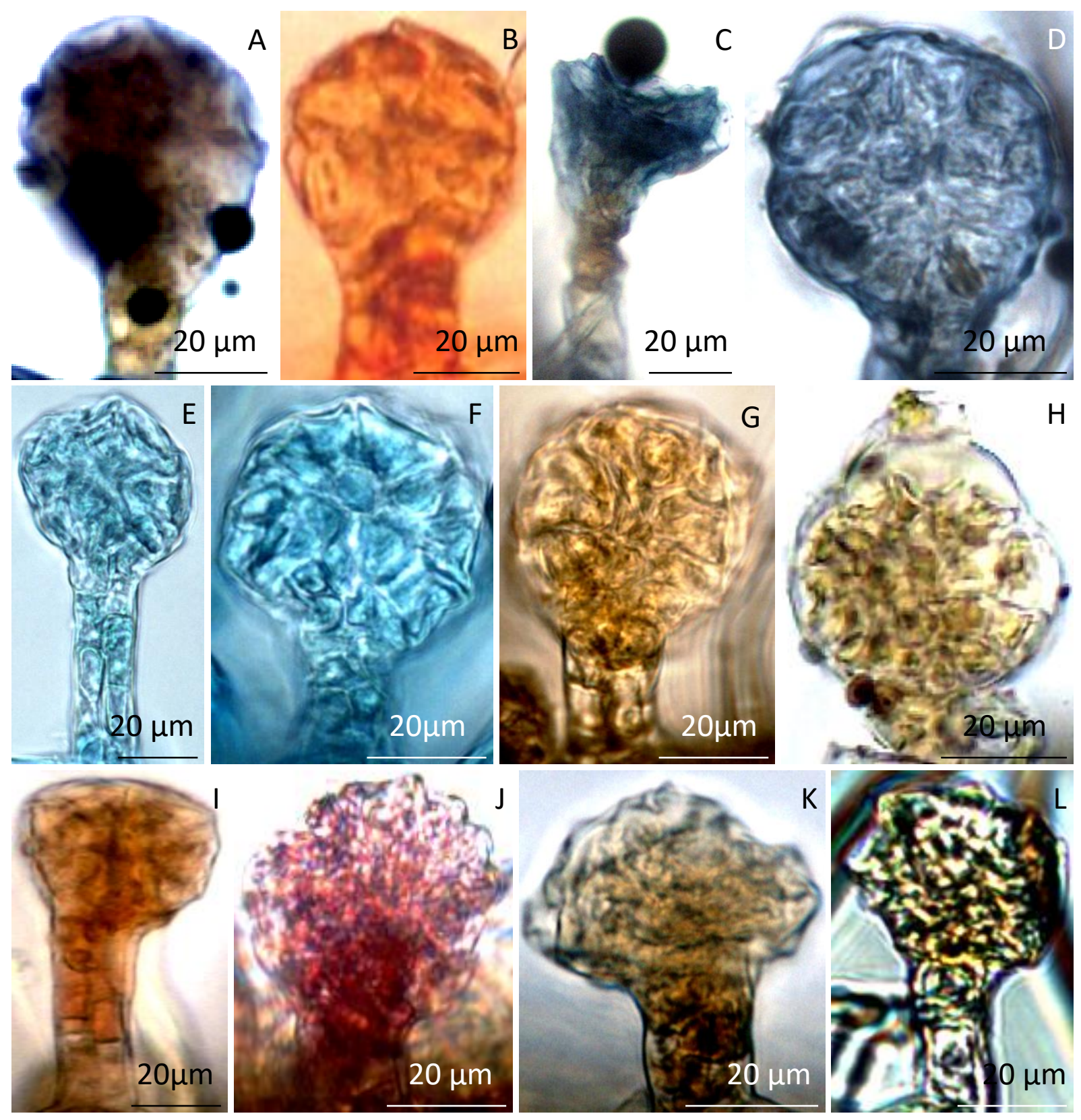

Figure 8A - L. Histochemistry of glandular trichomes in the adaxial epidermis of $R$. idaeus 'Laszka' and 'Radziejowa' leaves: A - terpene compounds stained dark purple (Nadi reagent); B - lipids - positive staining reaction - red (Sudan Red 7B); C, D - lipid compounds stained dark blue (Sudan Black B); E, F - acid lipids stained blue (Nile Blue); G, H - pectin compounds stained yellow (Lugol's solution); I - carbohydrates - staining reaction - red (Fehling's reagent); J - polysaccharides stained pink (periodic acid/Schiff reagent); K polyphenolic compounds stained brown (potassium dichromate) or black (iron chloride). 

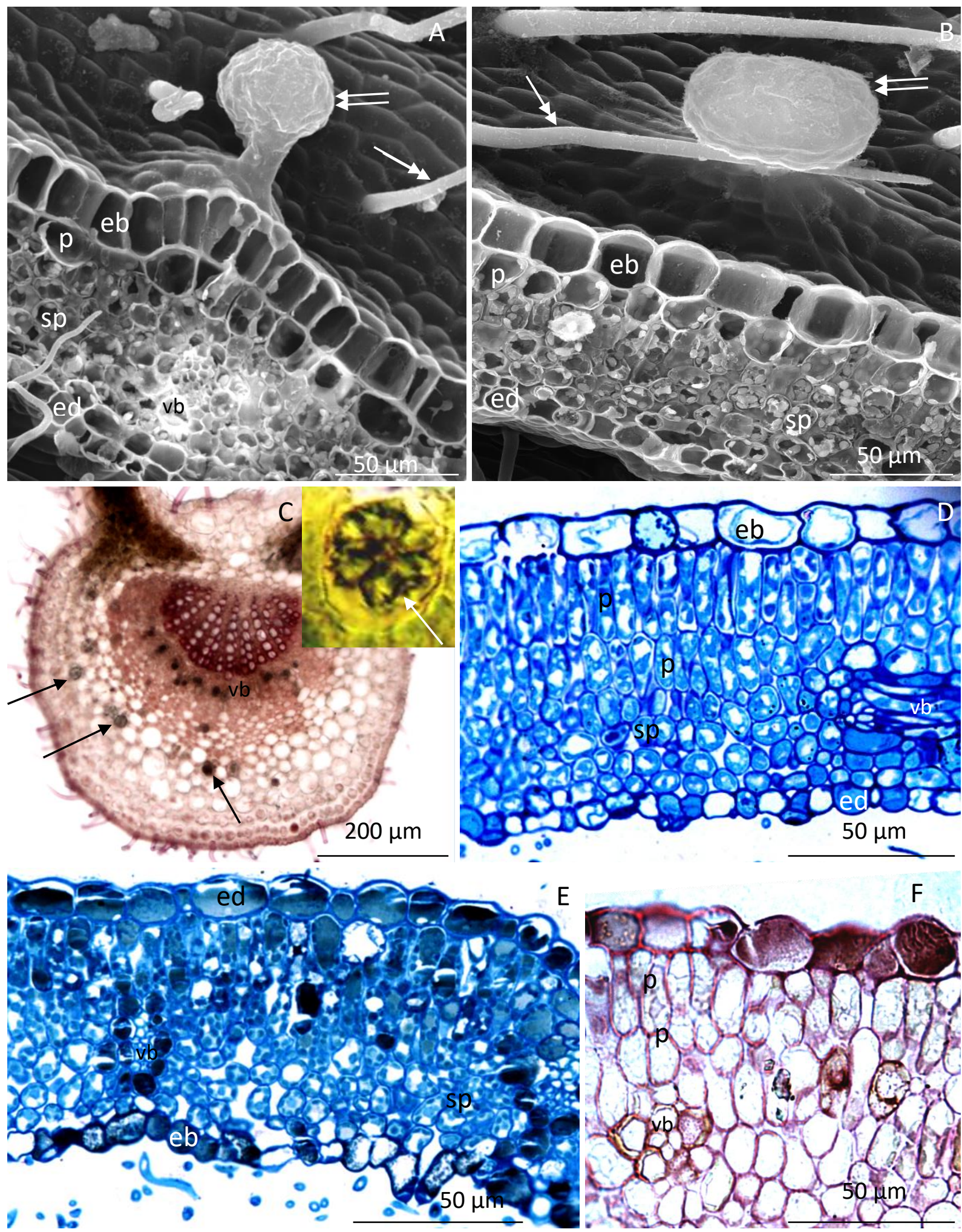

Figure 9A - F. Fragments of cross sections of $R$. idaeus 'Glen Ample' (C) 'Laszka' (A, D), and 'Radziejowa' (B, E, F) leaves: A, B - non-glandular (double arrowhead) and glandular (double arrows) trichomes, visible large abaxial epidermis cells (eb) and smaller adaxial epidermis cells (ed), palisade parenchyma cells (p), small spongy parenchyma cells (sp) with numerous plastids, visible vascular bundle elements (vb) (A); C - midrib, visible calcium 
oxalate druses (arrows); D - F - sections of 'Glen Ample', 'Laszka', and 'Radziejowa' leaves, visible abaxial epidermis cells (eb) and smaller adaxial epidermis cells (ed), one or two layers of palisade parenchyma cells (p) and spongy parenchyma cells (sp) with numerous plastids, vascular bundle (vb), and stomata (s) located above the epidermis cells. 

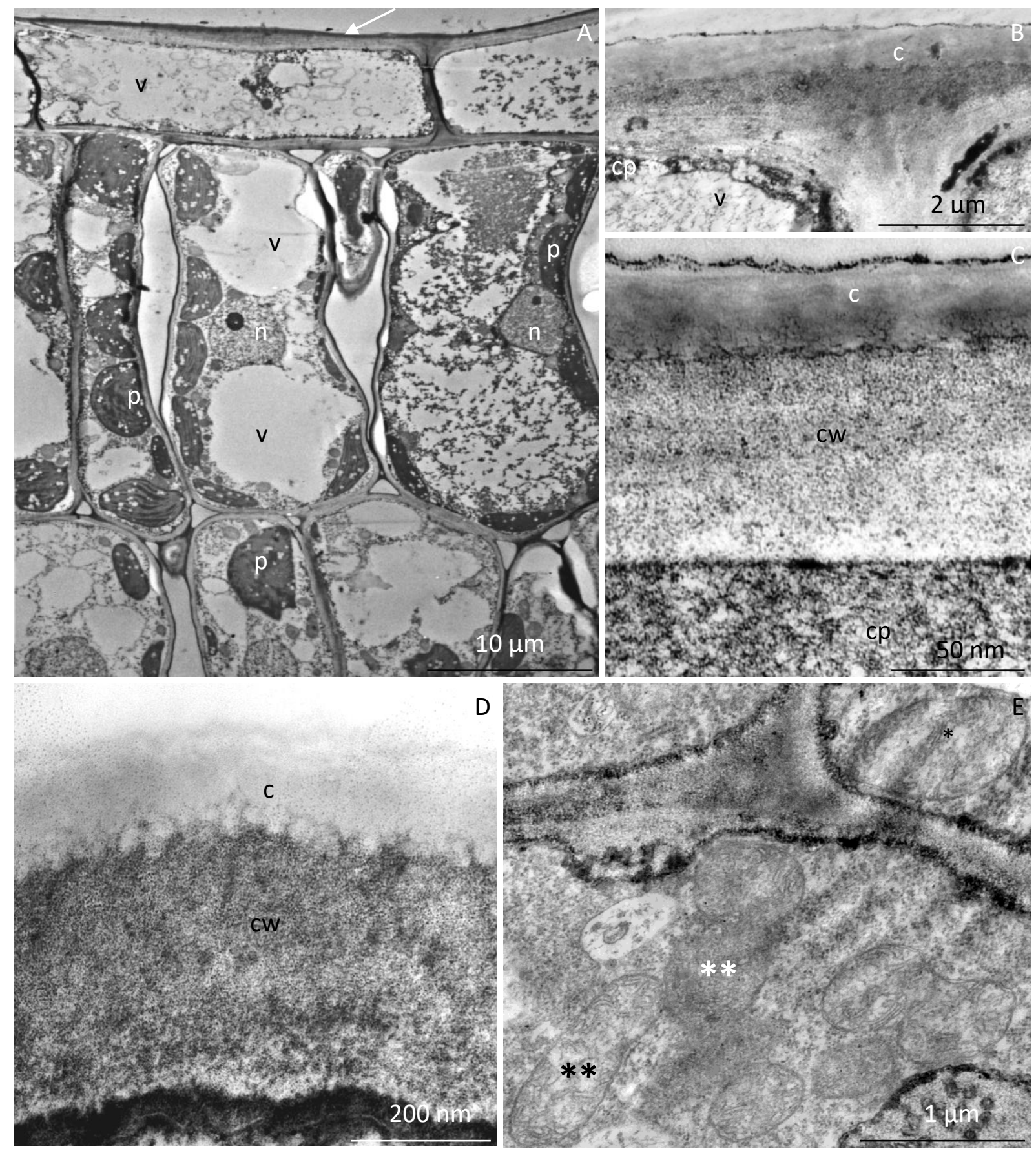

Figure 10A-D. Fragments of cross sections of the cells of adaxial epidermis and assimilation parenchyma in $R$. idaeus 'Radziejowa' leaves: A - adaxial epidermis and palisade mesophyll cells, visible thick cell walls (arrow) and a large central vacuole (v) in the epidermis cells; numerous plastids (p), large cell nucleus (n) with dense nucleoplasm, nucleolus, varied degree of vacuolization in assimilation cells; B - epidermis cells, visible periclinal outer cell wall (cw), cytoplasm, vacuole (v); C, D - epidermis cells, visible cuticle strand (c), the other part of the cell wall (cw), cytoplasm; D - single mitochondria in the epidermis protoplast (asterisk) and mitochondria clustered in the assimilation cell (double asterisk). 

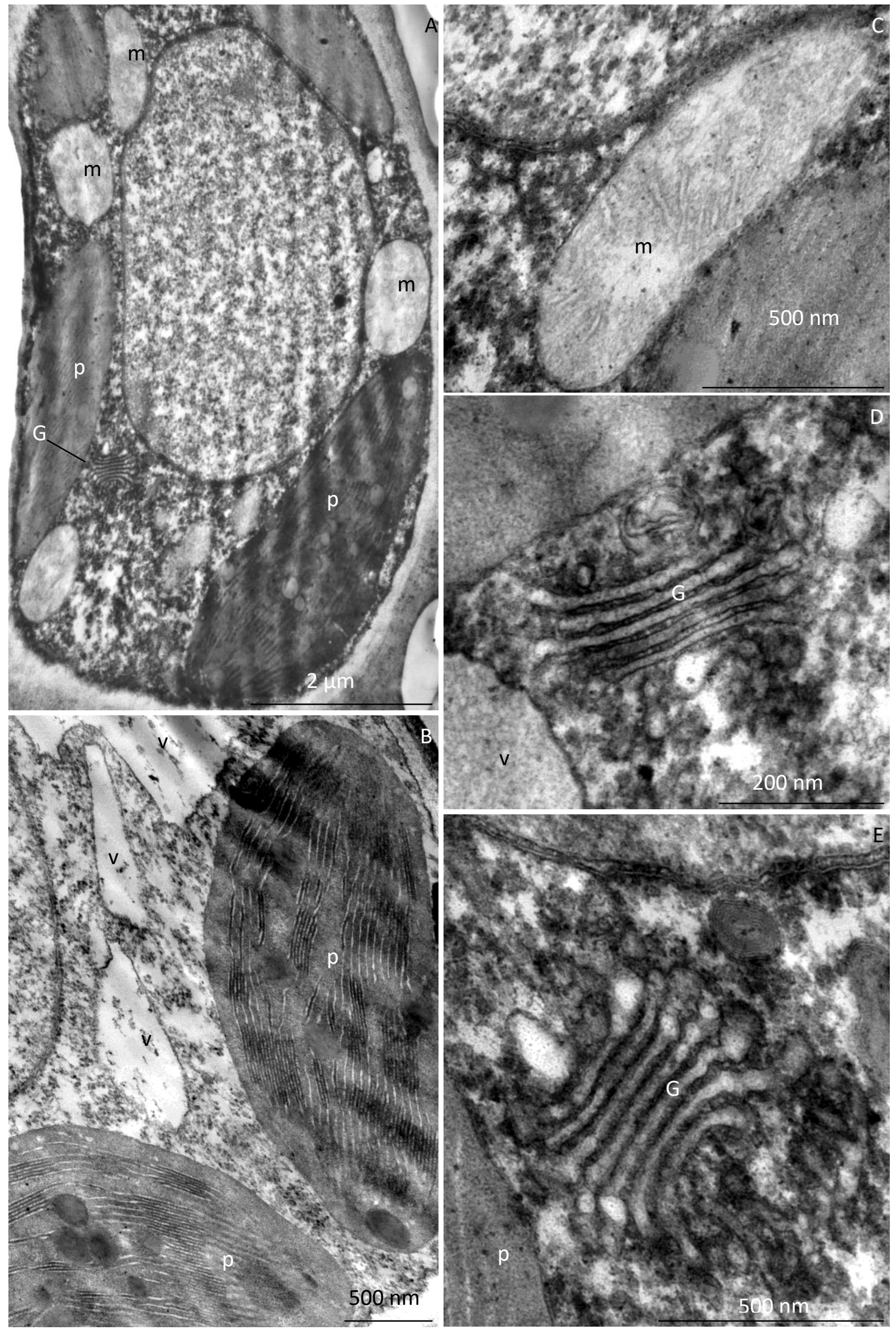
Figure 11A-G. Fragments of the cross sections of palisade mesophyll cells in $R$. idaeus 'Radziejowa' leaves: A - protoplast with parietal cytoplasm, visible plastids (p), mitochondria (m), Golgi apparatus; B, C - plastids (p) with a visible thylakoid system; C - mitochondrion; D, E - Golgi apparatus $(\mathrm{G})$ with visible cisternae and dictiosomal vesicles. 
Table 1. Size of glandular trichomes in the adaxial epidermis in two $R$. idaeus cultivars.

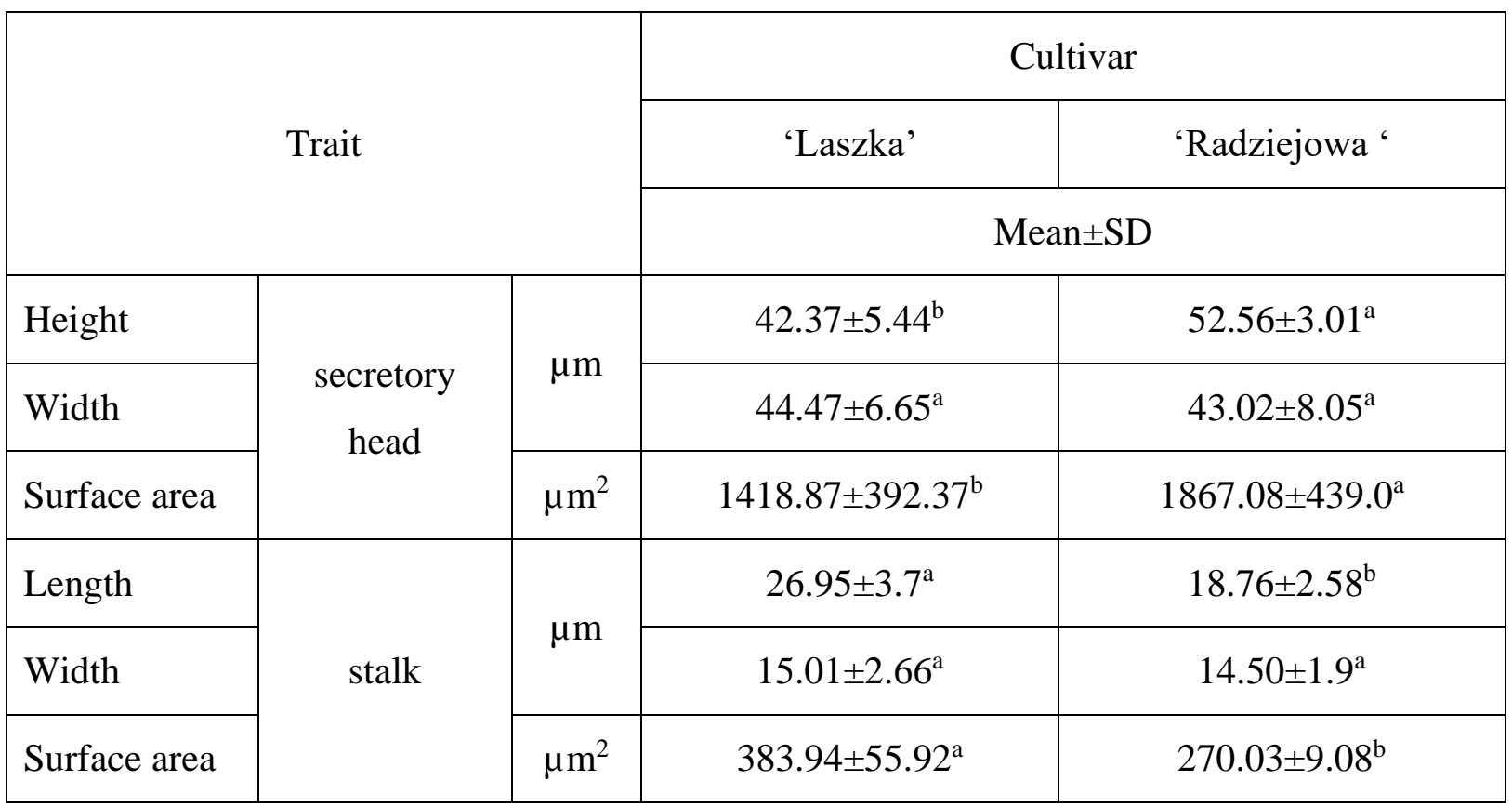

${ }^{a-b}$ means followed by the same letter are not significantly different between cultivars $(p \leq 0,05)$

Table 2. Size of stomata in the abaxial epidermis in three $R$. idaeus cultivars.

\begin{tabular}{|c|c|c|c|c|c|}
\hline & & & \multicolumn{3}{|c|}{ Cultivar } \\
\hline \multicolumn{3}{|c|}{ Trait } & 'Glen Ample' & 'Laszka' & 'Radziejowa' \\
\hline & & & \multicolumn{3}{|c|}{ Mean \pm SD } \\
\hline Length & \multirow{2}{*}{ of stomata } & \multirow{4}{*}{$\mu \mathrm{m}$} & $17.72 \pm 2.63^{b}$ & $10.03 \pm 1.15^{\mathrm{c}}$ & $21.82 \pm 2.92^{\mathrm{a}}$ \\
\hline Width & & & $16.21 \pm 0.61^{\mathrm{b}}$ & $7.82 \pm 0.57^{\mathrm{c}}$ & $19.43 \pm 1.27^{\mathrm{a}}$ \\
\hline \multicolumn{2}{|c|}{ Thickness of cuticular ledge } & & $3.02 \pm 0.46^{\mathrm{a}}$ & $2,66 \pm 1,07^{b}$ & $1.71 \pm 0.32^{\mathrm{c}}$ \\
\hline \multicolumn{2}{|c|}{$\begin{array}{l}\text { Length of the groove between } \\
\text { cuticular ledges }\end{array}$} & & $9.49 \pm 1.13^{\mathrm{b}}$ & $5.31 \pm 0.68^{c}$ & $11.56 \pm 1.38^{\mathrm{a}}$ \\
\hline
\end{tabular}

${ }^{\mathrm{a}-\mathrm{c}}$ means followed by the same letter are not significantly different between cultivars $(\mathrm{p} \leq 0,05)$ 
Table 3. Size of epidermis and mesophyll cells on the leaves of three R. idaeus cultivars.

\begin{tabular}{|c|c|c|c|c|c|c|c|}
\hline & & \multicolumn{2}{|c|}{ 'Glen Ample' } & \multicolumn{2}{|c|}{ 'Laszka' } & \multicolumn{2}{|c|}{ 'Radziejowa' } \\
\hline \multicolumn{2}{|l|}{ Trait } & Min. - Max. & Mean \pm SD & Min. - Max. & Mean \pm SD & Min. - Max. & Mean \pm SD \\
\hline \multirow{2}{*}{ Height of epidermis cells } & adaxial & $12.48-37.04$ & $19.05 \pm 6.62^{\mathrm{a}}$ & $7.62-21.21$ & $16.36 \pm 3.72^{\mathrm{a}}$ & $8.25-24.29$ & $16.82 \pm 4.55^{\mathrm{a}}$ \\
\hline & abaxial & $4.99-18.59$ & $9.35 \pm 3.71^{\mathrm{a}}$ & $5.63-12.78$ & $9.75 \pm 2.27^{\mathrm{a}}$ & $7.81-22.15$ & $14.15 \pm 4.32^{\mathrm{b}}$ \\
\hline \multirow{2}{*}{ Width of epidermis cells } & adaxial & $15.21-35.5$ & $23.79 \pm 6.3^{\mathrm{a}}$ & $11.83-37.62$ & $22.14 \pm 8.93^{\mathrm{a}}$ & $11.29-22.53$ & $16.51 \pm 3.01^{\mathrm{b}}$ \\
\hline & abaxial & $6.3-13.11$ & $9.89 \pm 1.67^{\mathrm{a}}$ & $6.91-18.36$ & $13.64 \pm 3.11^{\mathrm{b}}$ & $8.26-16.1$ & $12.4 \pm 2.36^{\mathrm{b}}$ \\
\hline \multicolumn{2}{|c|}{ Height of palisade parenchyma cells } & $30.14-44.12$ & $35.11 \pm 3.09^{\mathrm{a}}$ & $20.46-27.78$ & $24.62 \pm 2.13^{\mathrm{c}}$ & $14.58-37.38$ & $28.49 \pm 4.99^{b}$ \\
\hline \multicolumn{2}{|c|}{ Width of palisade parenchyma cells } & $4.62-10.44$ & $6.98 \pm 1.48^{\mathrm{c}}$ & $4.32-14.16$ & $7.67 \pm 2.07^{\mathrm{b}}$ & $5.26-12.96$ & $9.31 \pm 2.02^{\mathrm{a}}$ \\
\hline \multirow{2}{*}{ Thickness of parenchyma } & palisade & $42.54-64.73$ & $51.89 \pm 7.43^{\mathrm{a}}$ & $33.13-49.04$ & $42.11 \pm 5.54^{\mathrm{b}}$ & $38.24-58.06$ & $51.44 \pm 4.73^{\mathrm{a}}$ \\
\hline & spongy & $27.87-52.95$ & $38.63 \pm 7.55^{\mathrm{a}}$ & $30.34-46.5$ & $37.89 \pm 5.41^{\mathrm{a}}$ & $31.36-51.64$ & $40.75 \pm 5.46^{a}$ \\
\hline \multicolumn{2}{|l|}{ Thickness of lamina } & $115.66-134.22$ & $125.33 \pm 5.27^{\mathrm{a}}$ & $92.19-122.65$ & $104.71 \pm 8.55^{\mathrm{b}}$ & $108.89-133.29$ & $121.4 \pm 6.36^{\mathrm{a}}$ \\
\hline
\end{tabular}

${ }^{a-c}$ means followed by the same letter are not significantly different between cultivars $(p \leq 0,05)$ 
Table 4. The content of macro- and micronutrients in the leaves of three varieties of $R$. ideaus.

\begin{tabular}{|c|c|c|c|}
\hline \multirow{3}{*}{$\begin{array}{l}\text { Zawartość } \\
\text { pierwiastka }\end{array}$} & 'Glen Ample' & 'Laszka' & 'Radziejowa' \\
\hline & Mean \pm SD & Mean \pm SD & Mean \pm SD \\
\hline & \multicolumn{3}{|c|}{$(\mathrm{mg} / \mathrm{kg})$} \\
\hline Potassium & $12600 \pm 100.10^{\mathrm{c}}$ & $20000 \pm 297.55^{\mathrm{a}}$ & $14100 \pm 202.89^{b}$ \\
\hline Calcium & $4800 \pm 159.35^{\mathrm{a}}$ & $2730 \pm 155.33^{b}$ & $2610 \pm 81.86^{b}$ \\
\hline Magnesium & $2800 \pm 108.63^{\mathrm{b}}$ & $2100 \pm 115.16^{\mathrm{c}}$ & $3610 \pm 120.48^{\mathrm{a}}$ \\
\hline Phosphorus & $2550 \pm 239.29^{a}$ & $2463 \pm 190.04^{\mathrm{ab}}$ & $2090 \pm 146.34^{b}$ \\
\hline Iron & $176 \pm 16.21^{\mathrm{c}}$ & $833 \pm 51.15^{\mathrm{a}}$ & $251.5 \pm 19.36^{\mathrm{b}}$ \\
\hline Sodium & $<0.250^{\mathrm{a}}$ & $<0.250^{\mathrm{a}}$ & $<0.250^{\mathrm{a}}$ \\
\hline Copper & $10.70 \pm 1.03^{\mathrm{b}}$ & $34.10 \pm 1.44^{\mathrm{a}}$ & $11.4 \pm 0.43^{\mathrm{b}}$ \\
\hline Zinc & $34.30 \pm 3.35^{\mathrm{a}}$ & $40.0 \pm 2.94^{\mathrm{a}}$ & $40.05 \pm 2.93^{\mathrm{a}}$ \\
\hline Lead & $0.0018 \pm 0.0001^{\mathrm{b}}$ & $0.0021 \pm 0.0003^{\mathrm{ab}}$ & $0.0023 \pm 0.0002^{\mathrm{a}}$ \\
\hline Cadmium & $0.0026 \pm 0.00034^{\mathrm{a}}$ & $0.0029 \pm 0.00036^{\mathrm{a}}$ & $0.0007 \pm 0.00014^{\mathrm{b}}$ \\
\hline
\end{tabular}

${ }^{\mathrm{a}-\mathrm{c}}$ means followed by the same letter are not significantly different between cultivars $(\mathrm{p} \leq 0,05)$ 


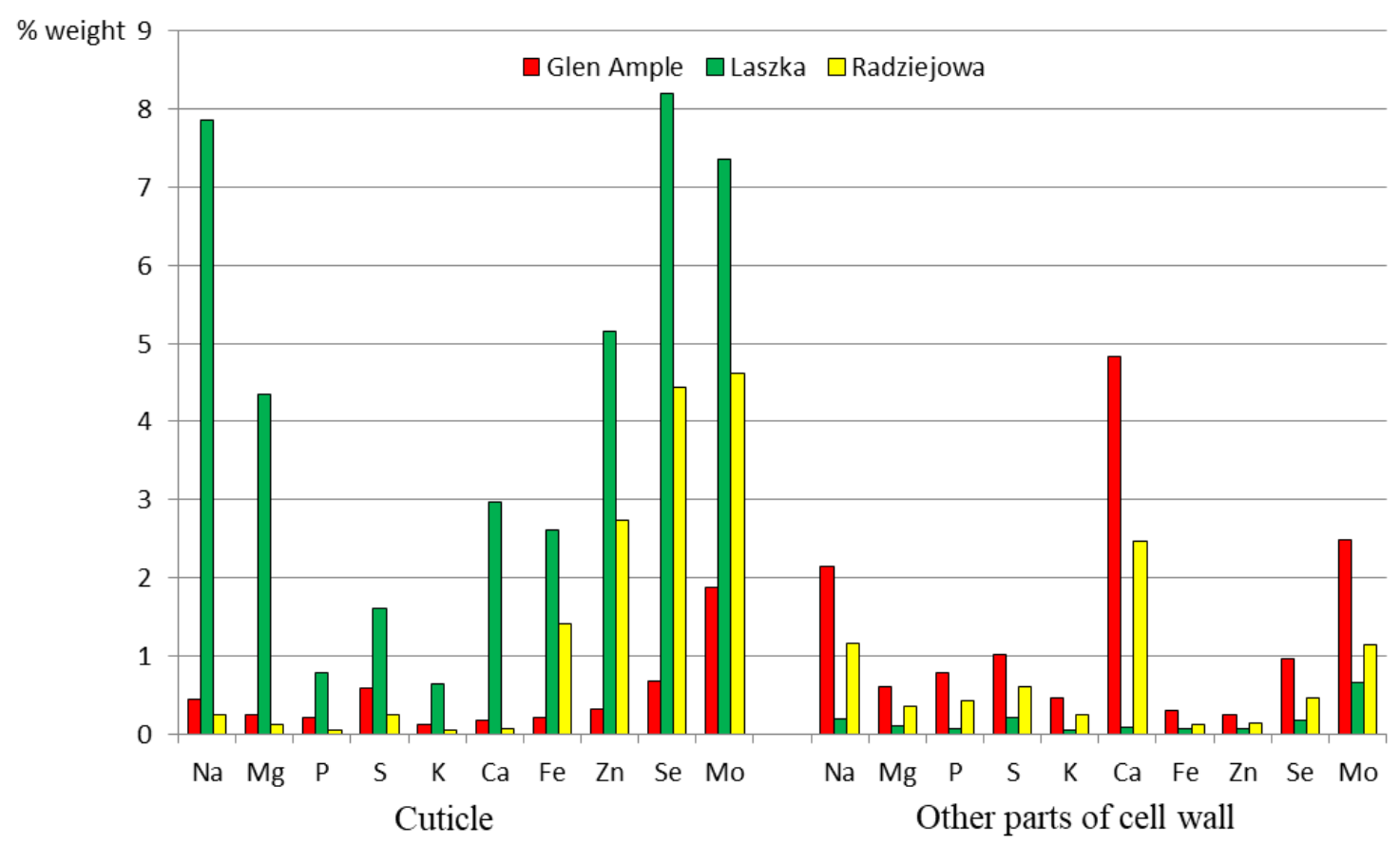

Figure 12. Content of selected elements in cuticle and other parts of the cell wall of epidermal cells in the leaves of three $R$. idaeus cultivars

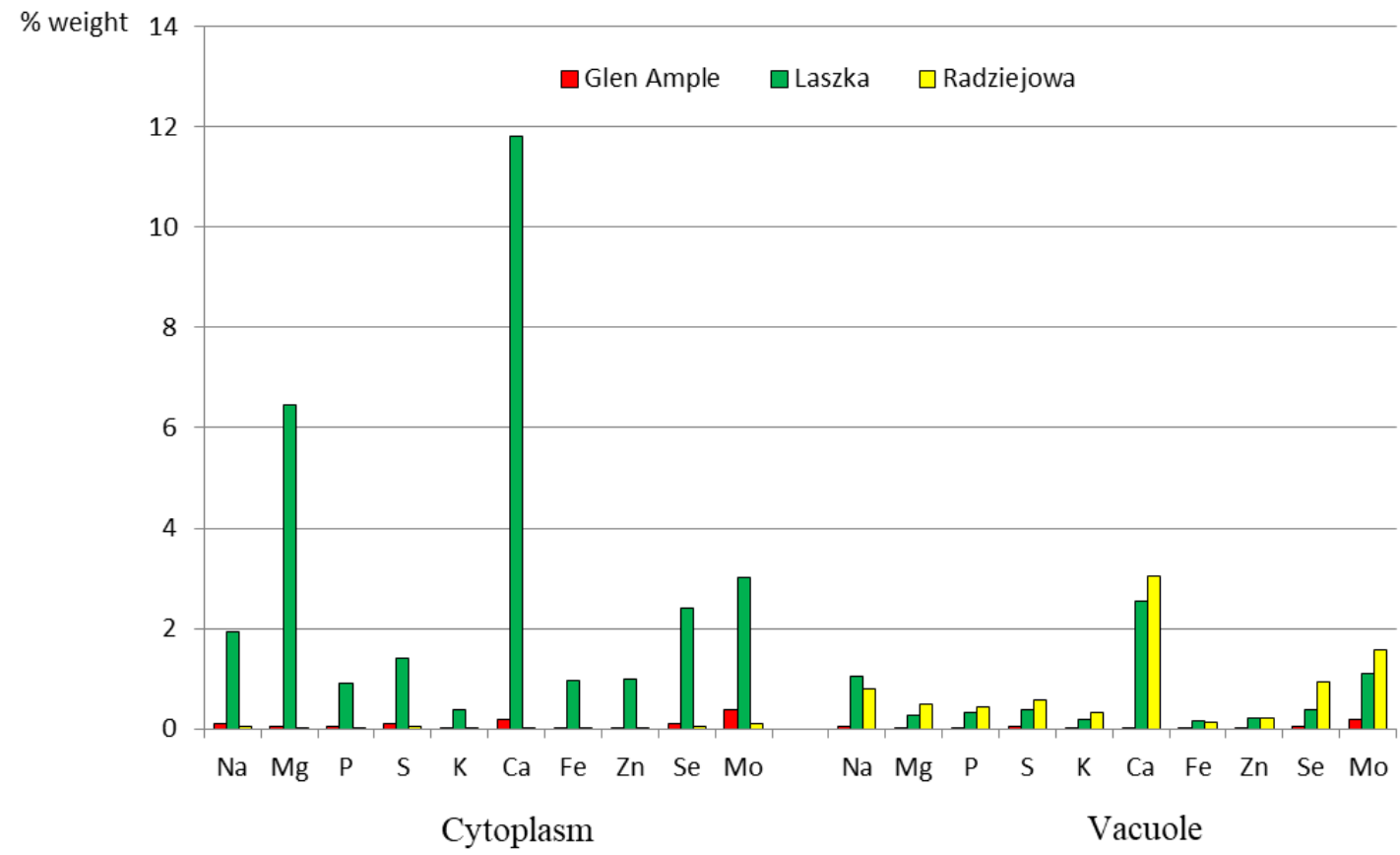

Figure 13. Content of selected elements in cytoplasm and vacuole of epidermal cells in the leaves of three $R$. idaeus cultivars 